FIELD MUSEUM OF NATURAL HISTORY DEPARTMENT OF ANTHROPOLOGY

\author{
GUIDE \\ PÀTT 1
}

\title{
ORIENTAL THEATRICALS
}

BY

BERTHOLD LAUFER

Curator of Anthropology

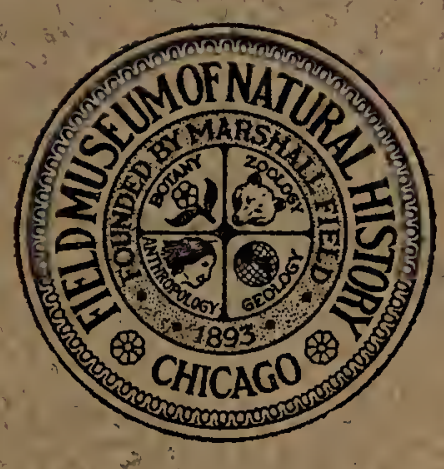

CHICAGO, U. S. A. 




\title{
Field Museum of Natural History DEPARTMENT OF ANTHROPOLOGY
}

\author{
GUIDE \\ PART 1 \\ ORIENTAL THEATRICALS \\ BY \\ BERTHOLD LAUFER \\ Curator of Anthropology
}

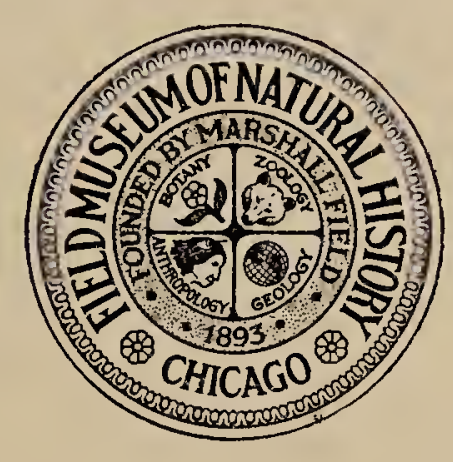

CHICAGO, U. S. A. 


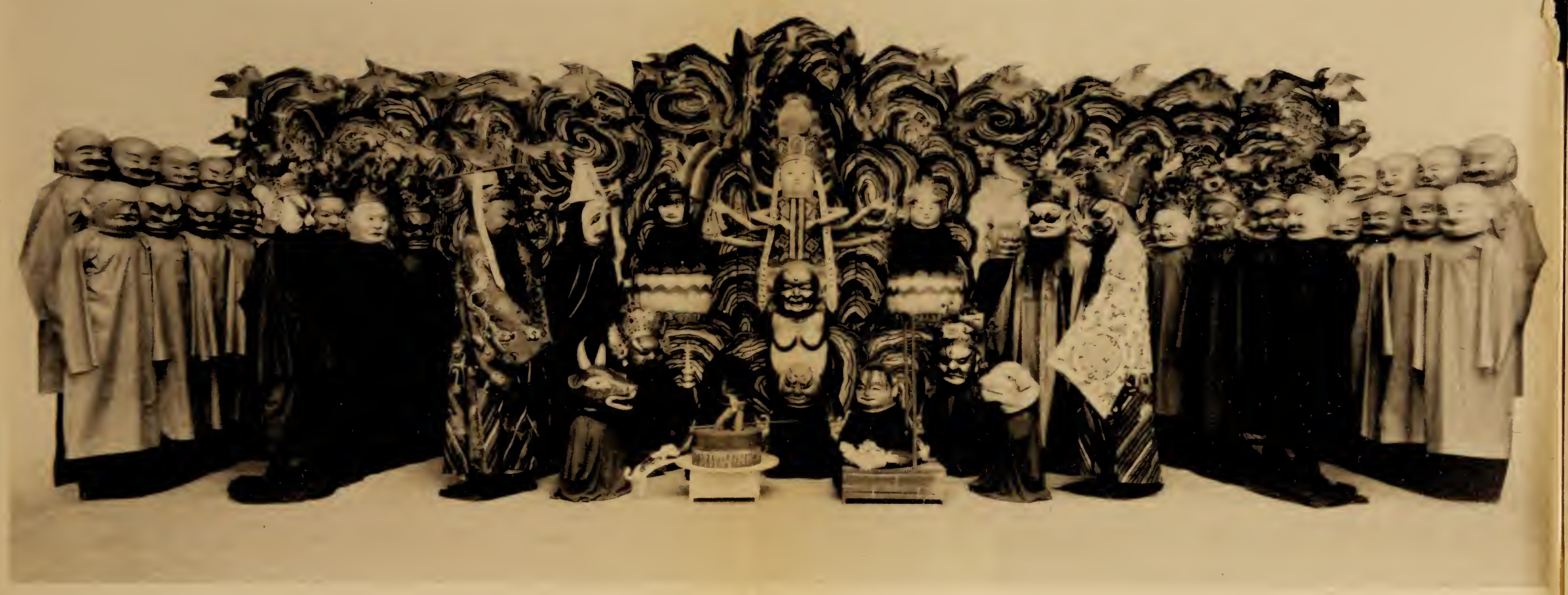

SCENE FROM CHINESE RELIGIOUS DRAMA, AS DISPLAYED IN FIELD MUSEUM (Hall I, Case 1): THE JUDGE OF PURGATORY AND HIS ASSISTANTS PASSING SENTENCE ON THE SHADES OF THE DEAD. 


\title{
Field Museum of Natural History
}

DEPARTMENT OF ANTHROPOLOGY

\author{
GUIDE \\ PART 1
}

\section{ORIENTAL THEATRICALS \\ BY \\ BERTHOLD LAUFER \\ Curator of Anthropology}

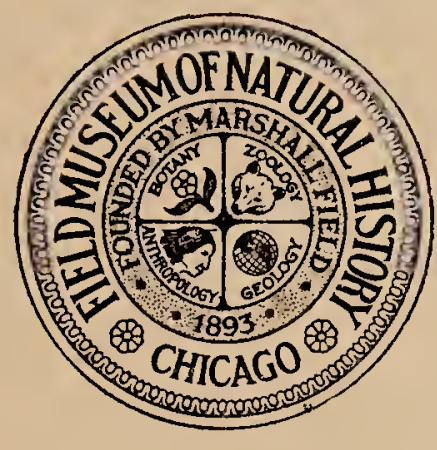

CHICAGO, U. S. A. 


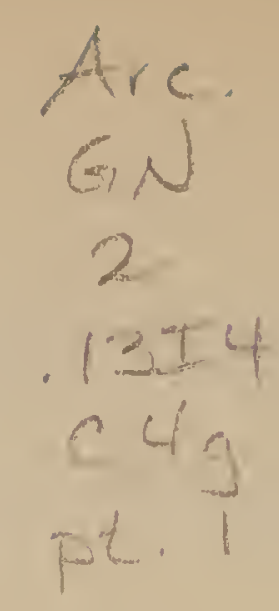

\section{CONTENTS}

The Religious Drama of the Chinese . . $\quad 3$

The Lion-Dance, China $\quad . \quad . \quad . \quad . \quad$. 29

Imperial Play, China . . . . . . 30

The Shadow-Play, China . . . . . 36

The Tibetan Mystery-Play . . . . . 42

The Theatre in Java

Singhalese Masks $\quad . \quad$. . . . . . 57

\section{$4 \div 786$ \\ $24876 ?$}




\section{ORIENTAL THEATRICALS}

(Hall I, Ground Floor)

In this Hall the popular entertainments and theatrical performances, as practised in Oriental countries, are grouped together for the purpose of illustrating, as far as the collections at present in the Museum's possession permit, the development and the present state of dramatic art in the Orient. It is proposed to increase and extend these exhibits considerably in the near future.

The exhibits are arranged in geographical order, proceeding from west to east, as follows :-

1. Chinese religious drama, showing the ten purgatories (Cases 1-4).

2. The Lion-Dance, China (Case 5).

3. Chinese masks from an imperial play, illustrating gods and heroes of the Taoist religion (Cases 6-7).

4. Chinese shadow-play figures (Cases-8-9).

5. Masks and masked figures of Tibetan mystery-plays (Cases 10-17).

6. Puppets or marionettes and orchestra accompanying performances, Java (Cases 1821).

7. Masks, actors' head-dresses and costumes, Java (Cases 22-24).

8. Singhalese masks, Ceylon (Cases 25-28). 


\section{THE RELIGIOUS DRAMA OF THE CHINESE}

In formulating the ideas of the future life, the Brahmans of India built up a system which has become the high model of all nations of the East. It is based on the fundamental belief in perpetual rebirth and the effects of Karma; that is, retribution in another state of existence for every good or evil action performed in the present. Thus, every individual is self-responsible for his present condition of life, as it is believed to be the result of his conduct in a previous form of existence. To the Indian, pinning his faith on the dogma of metempsychosis, the sojourn in Purgatory is merely transitory, an episode in the constant flight of numerous, successive existences, which may be interrupted at a time when, by saintly conduct, the state of self-destruction, or cessation of all consciousness of existence, the Nirvana, will be reached. There is, accordingly, in Buddhism no belief in everlasting punishment; there is always hope of a final redemption. The torment limited in time is a temporary stage which effects the purification of the soul; and the culprit, running through countless evolutions, at length has an opportunity to improve his moral and physical condition when he will be reborn anew. The descent into Purgatory, consequently, is an incident in the great cycle of transmigrations, and the path which may finally lead to salvation. Nor is Purgatory itself an eternal institution; it is as destructible as this system of worlds (in the Buddhist sense), and will perish in the great conflagration befalling the present world-cycle at the end of a Kalpa (a period of a hundred thousand years). The ethical influence of this belief on the conduct of his votaries must not be 
underrated; it has acted as a moral stimulus on the lives of millions in the East to whom the esoteric teachings of religion are too lofty to grasp, and who are in need of a tangible memento mori.

In the pre-Buddhist age of China there was a belief in a future life, but the conceptions of the future abodes were extremely vague. Confucius, though reluctant to discuss any questions concerning the dead, recognized a continuation of this life by upholding ancestor-worship. The numerous objects of jade, bronze, pottery, and clay interred in the graves of ancient China demonstrate vividly the people's yearning for the bliss of a greater beyond. Taoism promised immortality as the reward of merit. A clear conception of a future state of happiness for the good and of torment for the wicked took root in China only with the transplantation of Buddhism from India, when, as a great educational means, it deeply agitated and uplifted the masses. The artists seconded the priests by depicting the torments of Purgatory on the walls of temples, or in setting them up in life-size clay models in niches along the temple court-yards. In China, as elsewhere, this was the grossly sensual means used to deter the people from crime and to hold them on the path of righteousness. Wu Tao-tse, the great artist of the T'ang period, is said to have painted scenes of Purgatory, the mere sight of which, it is recorded, made the beholders sweat, and their hair to stand on end. It inspired the butchers and fishmongers at the capital with such a degree of horror that many of them felt compelled to abandon the trades against which the anathema of Buddhism was hurled, and to seek a livelihood in other directions. An art-critic who saw this work and describes its effects on the contemporaries, 
concludes his discourse by saying, "It has caused them to seek after virtue and give up evil practices; after which, who can say that painting is only a small art?"

"But the Chinese," observes Rudyard Kipling on his visit to the Temple of Horrors at Canton (From Sea to Sea, Ch. X), "are merciful even in their tortures. When a man is ground in a mill, he is, according to the models, popped in head first. This is hard on the crowd who are waiting to see the fun, but it saves trouble to the executioners. A half-ground man has to be carefully watched, or else he wriggles out of his place." It must not be supposed, of course, that the Chinese have ever in reality practised the tortures demonstrated in the ten courts of Purgatory. This lore is not their own, they adopted it from India. It is the visual illustration of what is minutely described in the sacred books of the Buddhists. On the stage, moreover, for which these models are designed, everything is mitigated and permeated by a willful, grotesque humor which makes it difficult for the spectator to take these punishments too seriously. Sceptical and rationalistic as many of the Chinese are, they will be moved to smile at this performance or to entertain doubt as to its reality. The baroque features and semicomic gestures of the devils contribute to the relief and exhilaration of the audience. The visitor should bear in mind that he is witnessing a fine piece of scenic illusion, which, while moralistic at its root and ethical in its tendency, is far from being calculated to shock the nerves or frighten the conscience, but which, on the conirary, will encourage and elevate by pointing the way to ultimate salvation. The keynote of this drama is not misery and despair, but hope and the possibility of self-perfection. 


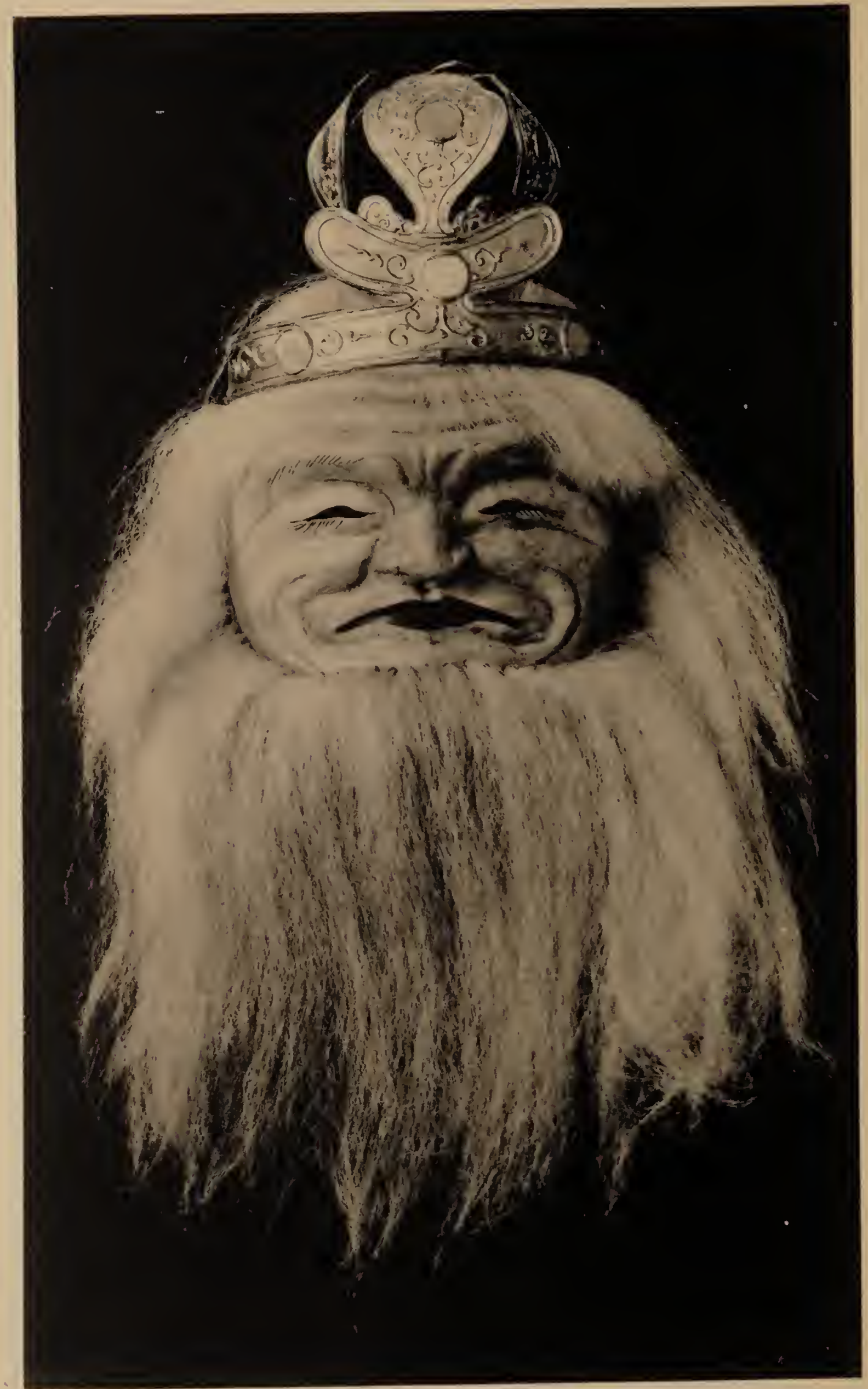

MASK OF KIANG TSE-YA, CHINA (p. 32). 
Salvation is the dominant factor, the sole great goal of religious life in the East. If, as has been said, the average Chinese lives merely for the purpose of being buried, if he lavishes a fortune on his coffin and his funeral, this indicates that he cares more for the future than for the present life and that consequently he makes his preparations thoroughly and in earnest faith. The chief personification of the idea of salvation in popular belief is the goddess of compassion, Kuan-yin, the Madonna of the Buddhists. Her statue with eight arms occupies the centre of the great stage scene, smiling forgiveness and holding out mercy and succor even to the hardened sinner. The contrast between this personification of tender leniency and the stern and immovable god of the lower region, who is also styled the king of the law, is striking; and a more potent and artistic antithesis could not have been conceived by the playwright.

This religious drama is an apotheosis of that most popular deity. According to Chinese tradition, she was brought up as the daughter of a powerful monarch. She took no interest in court life, but turned her thoughts toward religion. She declined to be married in accordance with her father's will, and determined to enter a monastery as a nun. The enraged king had her immured in a convent, where she was assigned degrading duties in the kitchen. Ill treatment did not break her spirit. The sword, by the blow of which she was to be executed at her father's command, splintered into pieces without harming her body. Thereupon she was strangled, when her pure soul wandered away and descended into the infernal regions. The appearance of her beneficent spirit wrought a miracle and converted hell into paradise: the shades of the 
tormented culprits felt a sudden relief from their agonies. Yama, the god of the inferno, stood aghast at this interference with what he considered law and justice, fearing that his authority might be jeopardized. In order to restore his reputation, he revived the body of the princess and set her afloat on a lotus, which drifted to the Island of $\mathrm{P}^{\prime} \mathrm{u}-\mathrm{t}^{\prime} \mathrm{o}$ in the Chusan Archipelago, where she lived for nine years, healing disease and rescuing mariners from shipwreck. Subsequently when her father fell ill, she sacrificed her hands and eyes, and made of them a medicine which saved his life. Finally she converted him to Buddhism and obtained the rank of a Buddha. After her death she was canonized and glorified as goddess of mercy, divine grace, and child-blessing, and as such she is still adored all over China and Japan, being frequently represented with a child in her arms. The climax of the drama is reached in her descent to the nether world and her vision of the fate of the damned.

The painted background of the stage is intended to represent the Island of $\mathrm{P}^{\prime} \mathrm{u}-\mathrm{t}^{\mathrm{c}} \mathrm{o}$. The many birds spread over the rocks serve as lanterns, a candle being stuck into a spike, so that during the performance the whole background is illuminated, which lends to the scene a magical effect. $\mathrm{P}^{\prime} \mathrm{u}$-t'o is a solitary rocky isle and a most beautiful spot, where nature and architecture have vied with each other, and are felicitously blended into an harmonious unit. Only the devotion and fervor of Buddhist priests, combined with their innate sense and love of nature, could have overcome the difficulties in making a little paradise of these rocks constantly lashed by the fury of the ocean. It is no wonder that this isle was chosen as the seat of Kuan-yin, the goddess of universal love, and that, with its temples, it 
is entirely devoted to her worship. It is a curious fact that despite the feminine character of this deity, who is a favorite with women, the monastic rules of the place forbid women to settle there; they may certainly come for brief visits to offer incense and worship, or to make donations to the temples, but they are not allowed to remain. Even the laymen in the employment of the priesthood are forbidden to contract marriages.

In Buddhism, the topography of the lower regions is a complicated system. Eight hot hells are assumed to be situated underneath the earth; but, as each of these establishments has four gates, and outside each gate are four ante-chambers, there are thus altogether 128 hot hells. In addition to these there are cold hells, also eight in number, arranged shaft-like, one beneath the other. This shaft is so shaped that it gradually widens down to the fourth hell, and then narrows again, the first and last hells having the smallest; and the fourth, the greatest diameter. There are, further, eight dark hells. Any individual dying in the first of these hells is at once reborn in the second, and so forth, the period spent in each of them lasting five hundred years. Finally, there are 84,000 small hells, situate on the edge of the universe, which are divided into three classes, according to their location on mountains, on water, or in deserts. There are different torments in the various hells, and the length of detention also varies in each class. People are reborn in one or the other according to their previous merits or demerits. The decision rests with Yama, the king of the infernal regions, who, assisted by eighteen judges and hosts of demons, orders what place and torture are appropriate in each instance. The Taoists adopted this system of retribution from the Buddhists, 
but simplified it, contenting themselves with ten purgatories, the presiding regents of which are partially associated with the gods of the sacred mountains. It is this conception of purgatory which, with a certain humorous flavor, is shown on the stage in this play. The first purgatory and its paraphernalia are displayed in Case 1, the nine others are installed in the adjoining Cases 2-4.

The visitor should bear in mind that only the figures in the center and foreground of Case 1 represent the real actors, those in the background and on the sides being merely supers. The scene is laid in a temple on the Isle of $\mathrm{P}^{\prime} \mathrm{u}-\mathrm{t}^{\mathrm{t}} \mathrm{o}$, and the statue of the goddess Kuanyin dominates the altar. She is surrounded by two male and two female attendants. The "Golden Monk" in front of the altar is intended to represent a bronze temple-statue of a Buddhist monk, which is placed in all temples as a sort of guardian.

The chief actor in front is King Ts'in Kuang, absolute sovereign and chief judge in the First Court of Purgatory. His expressive mask is thoroughly characteristic of his infernal majesty, firm, stern, solemn, and bent on meting out justice according to the immutable and inexorable law of his kingdom. In harmony with his exalted position and rank, he is clothed with the imperial robe richly embroidered with dragons and ornamental forms of the character meaning "longevity." Euphemistically he is not regarded as the god of death, but as the ruler of life. His headdress corresponds to that of the ancient emperors of China: sun, moon, the dipper, and earth are represented on the flat board.

In front of the King is the mask of "General Bull," who has the function of a beadle. He is bull-faced, 
because the bull is sacred to Yama, the ancient Indian god of death, who is usually represented as standing on the back of a bull, or even with a bull's head (cf. Chinese clay figures in Case 18, East Gallery). Opposite are the chief assistant judges. One is a civil officer who takes part in the judicial proceedings. On his official robe are embroidered in gold two blazons with the design of a phœnix looking toward the sun. The other is a military officer in charge of the proper execution of punishments, whose costume is embroidered with golden dragons rising from the sea, with rocky islands below.

The infernal regions are believed to be organized on much the same model as the world above, except in the matter of light. A chancery is established in each of the Ten Courts, and business is conducted on the same lines as in a Yamen, with a staff of secretaries. The three devil-lictors, behind the tortured, represent the infernal police, and have executive power. They arrest the souls of dying persons, being armed with warrants signed and sealed in due form as in the official world above. They drag the culprits who have been duly sentenced to the tortures assigned to them, and see to the execution of the punishment according to the letter of the law. They are divided into various ranks, with a major classification of "big" and "small" devils. The resemblance of their types with our mediæval devils is unmistakable; the same horns and fangs, the same dishevelled hair, the same black or colored faces, and the same diabolic expressions. Their hair is red, yellow, blue, or black.

The "small devil" with a single horn on his head and protruding eye-balls and tusks, standing to the left of the King, is placed under the latter's immediate 
command, and is the chief executioner. His vest is lined with a tiger-skin emblematic of his "tiger-heart."

As the Judge is often obliged to arrest culprits still living on earth, he has created the office of bailiff or sheriff. The infernal police is not eligible for this dignity, unable as they are to stand the light of the day. The bailiff, therefore, must be of human origin, and it is the ghost of a man who has committed suicide by hanging himself who is appointed; hence he is represented with a long, distorted face and protruding tongue. The four characters inscribed on his tall, white cap signify, "Great luck at one glance!" This means that those whose virtuous actions he has once observed will enjoy felicity, although arraigned before the Judge. In his capacity as lictor to the Tutelary Guardian of every town he has occasion to spy all good and evil deeds of people, which are duly recorded by him for transmission to the office of the lower region. He may also arrest, by order of the Judge, any evildoers or witnesses required in his judicial procedures.

The King of this first Court has the custody of the book of life and death, keeping a record of all living persons. Every man and woman appears after death before this Court, and if their tale of good and evil works is equally balanced, is thence. returned back to life. Male may become female; female, male; rich, poor; and poor, rich, according to the merits acquired during their lifetime. Those, whose good deeds are outnumbered by their bad ones, are sent to a terrace on the right of the Court, called the Terrace of the Mirror of Sin, ten feet in height. In this mirror the wicked souls are able to behold the crimes committed by them on earth. After they have been dragged by devils to the Terrace, they are sent forward into the Second 
Court, where they are tortured and dismissed to the purgatory appropriate to their crime. On the stage, an exception is made to this rule, and in order to lend more color to this scene, two tortures are introduced into the First Court. One consists of a mill between the stones of which a woman is ground, as a punishment for adultery; a dog is licking her blood. The other represents a rice-pounder in which culprits are crushed by the pestle. The person under the pestle has just been questioned and tortured, but a lotus sprouting forth from his chest bears witness to his innocence. He will be discharged as not guilty.

Among the supers is the group of Eighteen Arhat, the most advanced disciples of Buddha, who have reached the highest degree or saintship. In this drama they merely illustrate the statues of these saints, as grouped in two rows along the walls of many temples. The other supers represent casts derived from the great mythological romance entitled Fung shen yen $i$, a famed Taoist book of wonders and miracles. In front of the altar, on the right-hand side, is the mask of Erh Lang, worshiped as "the Veritable Prince of the Marvelous Tao" (the way to righteousness). He is the patron and guardian of the dogs. He owns a supernatural dog whose mask is beside him. He can carry this dog in the sleeves of his coat, and the dog devours any enemy at whom he is set. There is a temple at Peking in honor of this god, where a clay dog is placed at the foot of the altar. He who has a sick dog takes a dose of ashes from the censer on this altar and administers it as a remedy to the sick animal. If the cure is efficient, the grateful owner of the dog will offer one of clay to the deified healer.

In front of the Arhat, on the right-hand side, are 
posted the Four Guardians of the World, each protecting one side of the world-mountain Sumeru, as defenders of the Buddhist faith. In front of the altar, on the left, appears the mask of $\mathrm{Li}$ T'ien-wang, a Taoist conception of one of these Four Guardians and styled "the Heavenly King supporting the Pagoda." The pagoda carved from wood is carried by the actor in his left hand. In popular belief, it is of pure gold, seven inches high and capable of flight; it can lengthen itself to the height of eighty feet, whereupon it will return to its original proportions.

On the left-hand side, between the Great King and the Arhat, are four Taoist saints: In the foreground is Chao Kung-ming, who resides on the sacred Mount O-mei in Se-ch'uan, and who took part in the national war which ended the rule of the Shang dynasty and set up the house of Chou in its stead (1122 B.C.). He is followed by Po Kien, who was a hero of the mythical age and found a place in the lower region for the following reason. After his death, his soul wandered about for a millennium, searching in vain for a body into which it might enter. Finally he was rescued by a recluse and built the terrace where the souls of the heroes slain in battle are sent, in order to receive appointments as spirits or gods. The duty thus devolved upon him to escort the souls to this terrace, and he ultimately received an appointment as the head of all spirits. The third is Huang, the "Flying Tiger" (Fei-hu), a hero, who at first fought on the side of the last ruler of the Shang dynasty, but disgusted with his evil doings rebelled against him and joined the forces of his adversary Wen Wang of the house of Chou. He was killed by Chang K'uei, the fourth in this row, who owns a magical horse, "Black 
Smoke" by name. "Black Smoke" is capable of covering five hundred miles a day and slaying seven men at a blow. Hence he is also honored with the epithet, the "Seven-Killer."

Attached to the background, on the right-hand side, are the masks of Yin Hung, son of the emperor Chousin of the Shang dynasty, who after many adventures was slain and canonized as the Spirit of the Five Kinds of Grain; and Mu Ch'a, who first battled under the standard of the Chou dynasty, but then retired into the solitude of the mountains to live the life of a recluse. His brother No Ch'a, who followed his example, is on the left-hand side of the background. There, also, is Yin Kiao, a brother of Yin Hung, canonized as the god of the year who resides on the planet Jupiter.

Taking leave of the First Court, we turn to the Second Court of Purgatory (Case 2, left of Case 1). Like Court I, it is believed to be situated at the bottom of the ocean. It is under the jurisdiction of King Ch'u Kiang, who rules over a vast realm many miles in extent and subdivided into sixteen wards, as follows:- In the first, nothing but black clouds and constant sand-storms. In the second, mud and filth. In the third, spikes and knives abound. The fourth is the abode of gnawing hunger; the fifth, of burning thirst. In the sixth, people sweat blood. In the seventh, the shades are plunged into a brazen cauldron filled with boiling water. In the eighth, they are tormented by sharp-edged brass tools. In the ninth, they are put into iron clothes. In the tenth, they are stretched on a rack to specified length. In the eleventh, they are pecked by fowls. In the twelfth, they have nothing but rivers of lime to drink. In the thirteenth, they are 
hacked to pieces. In the fourteenth, the leaves of the trees are as sharp as sword-points. In the fifteenth, they are pursued by foxes and wolves. In the sixteenth, all is ice and snow.

In this Court will be found those who filch letters, pictures and books entrusted to their care, and then pretend to have lost them; those who injure a fellowcreature; those who practise medicine without any knowledge of medical art; those who will not ransom grown-up slave-girls; those who, contracting marriage for the sake of gain, falsely state their ages, and many others.

On the stage is shown the torment of the Fiery Pillar, to which the culprits are tied to be roasted. The beadle, called "General Horse," wears the mask of a horse-head.

In the sixteenth subdivision of Court II there is a huge surface of smooth ice on which the culprits are thrust by the devil-lictors, and pushed and rolled to and fro, till their bodies become flattened out. The two figures represent the shades of a man and a woman whose bodies display the effects of this treatment.

Court III is under the jurisdiction of King Sung Ti. His realm is more than $500 \mathrm{li}$ (Chinese miles) in compass, being subdivided into sixteen wards:-The first is the place of brine-wells and salt-pits; everything is salt; above, below, and all around, the eye rests upon salt alone. The shades feed upon it, and suffer horrid torments in consequence. In the second, the culprits are bound with cords and carry heavy pillories. In the third, they are being perpetually pierced through the ribs. In the fourth, their faces are scraped with iron and copper knives. In the fifth, their fat is scraped away from their bodies. In the 


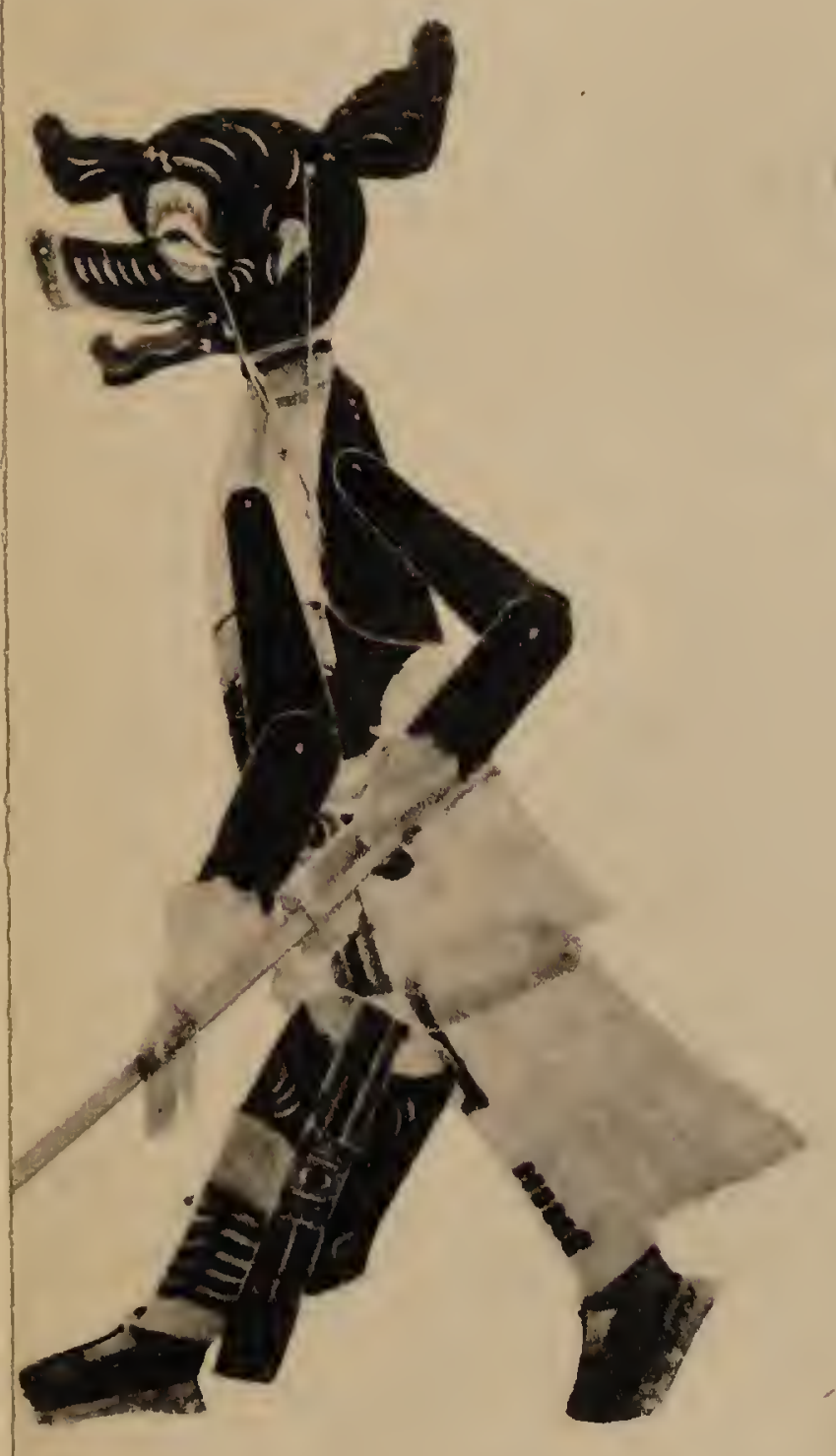

CHU PA-TSIE

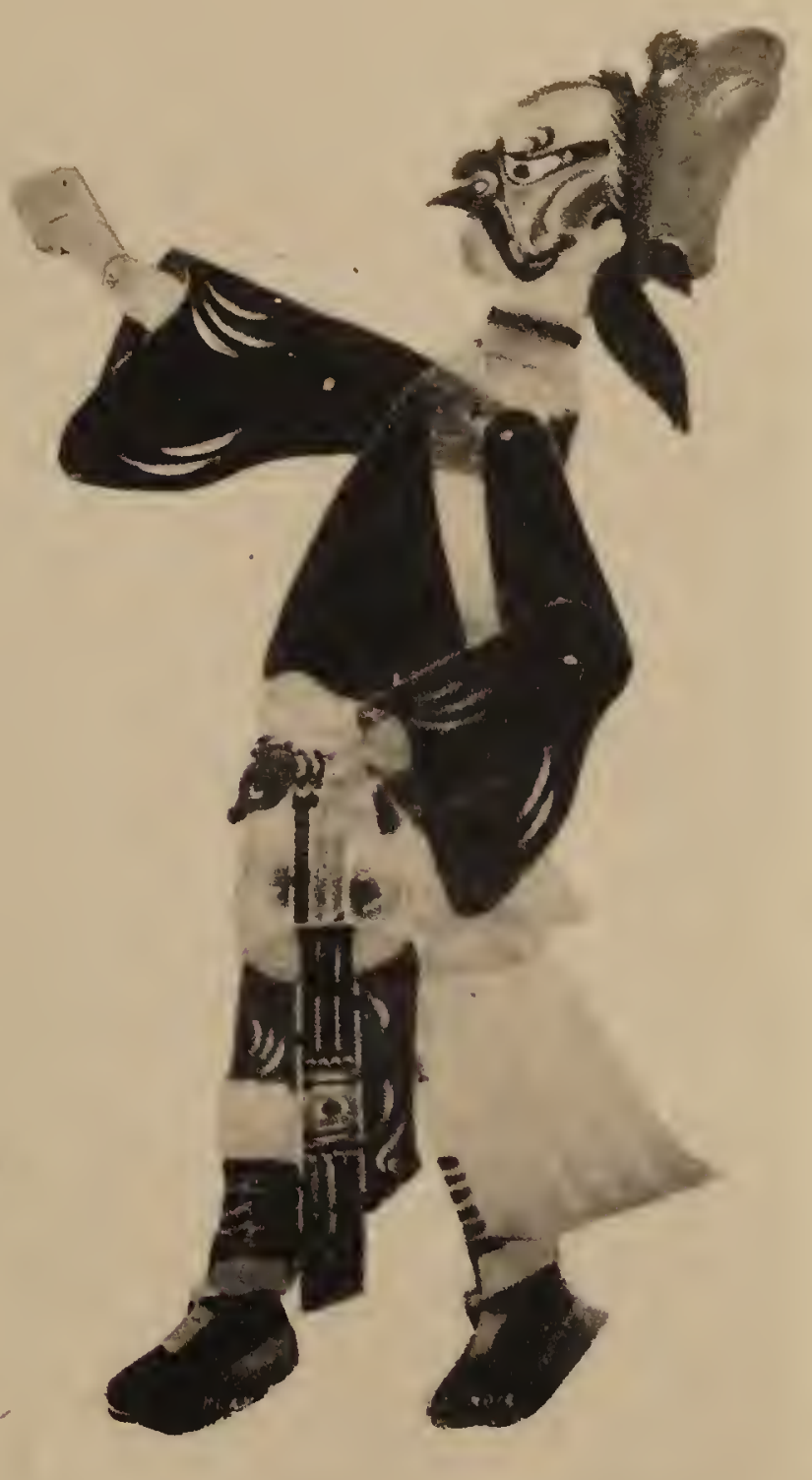

SHA WU-TSING 
hacked to pieces. In the fourteenth, the leaves of the trees are as sharp as sword-points. In the fifteenth, they are pursued by foxes and wolves. In the sixteenth, all is ice and snow.

In this Court will be found those who filch letters, pictures and books entrusted to their care, and then pretend to have lost them; those who injure a fellowcreature; those who practise medicine without any knowledge of medical art; those who will not ransom grown-up slave-girls; those who, contracting marriage for the sake of gain, falsely state their ages, and many others.

On the stage is shown the torment of the Fiery Pillar, to which the culprits are tied to be roasted. The beadle, called "General Horse," wears the mask of a horse-head.

In the sixteenth subdivision of Court II there is a huge surface of smooth ice on which the culprits are thrust by the devil-lictors, and pushed and rolled to and fro, till their bodies become flattened out. The two figures represent the shades of a man and a woman whose bodies display the effects of this treatment.

Court III is under the jurisdiction of King Sung Ti. His realm is more than 500 li (Chinese miles) in compass, being subdivided into sixteen wards:-The first is the place of brine-wells and salt-pits; everything is salt; above, below, and all around, the eye rests upon salt alone. The shades feed upon it, and suffer horrid torments in consequence. In the second, the culprits are bound with cords and carry heavy pillories. In the third, they are being perpetually pierced through the ribs. In the fourth, their faces are scraped with iron and copper knives. In the fifth, their fat is scraped away from their bodies. In the 


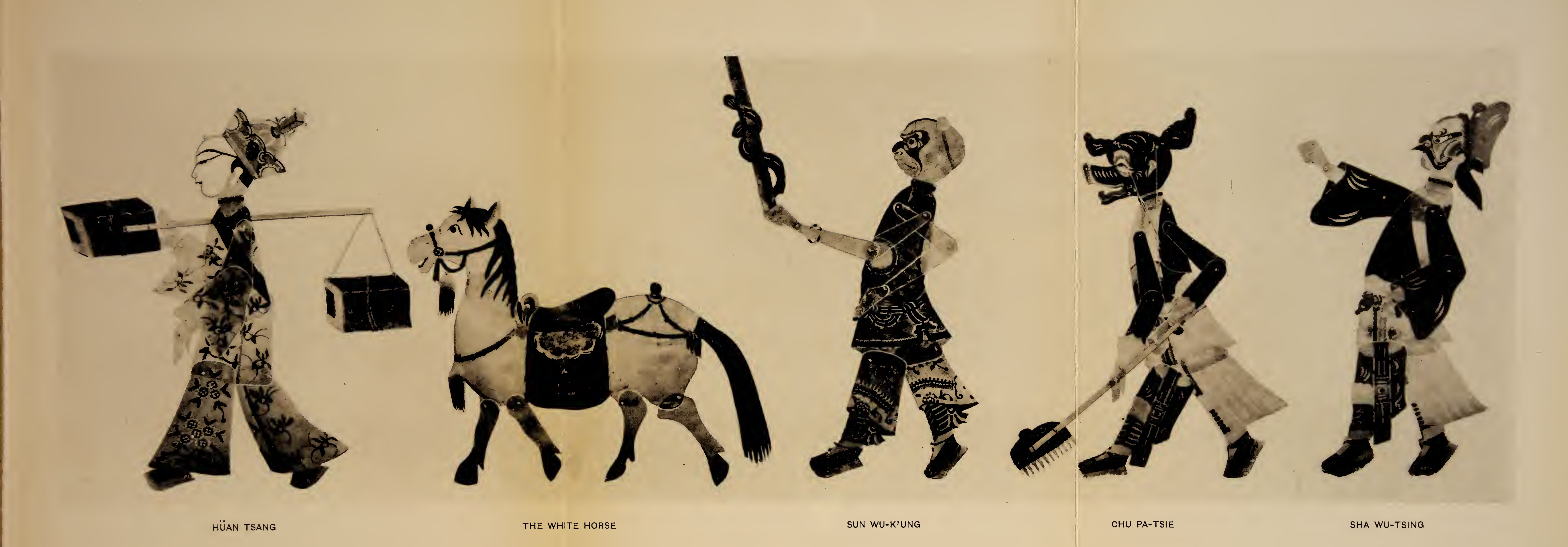


sixth, their hearts and livers are squeezed with pincers. In the seventh, their eyes are gouged. In the eighth, they are flayed. In the ninth, their feet are chopped off. In the tenth, their finger-nails and toenails are pulled out. In the eleventh, their blood is sucked. In the twelfth, they are suspended from their feet, head downward. In the thirteenth, their shoulderbones are split. In the fourteenth, they are tormented by insects and reptiles. In the fifteenth, their thighs and knees are beaten. In the sixteenth, their hearts are extracted.

In this Court will be found those who obstruct funeral obsequies or the completion of graves; those who lose all record of the site of their family buryingplace; those who incite others to commit crimes; those who promote litigation; those who repudiate a betrothal; those who forge deeds and other documents; those who counterfeit signatures and seals; those who alter bills; wives who slight their husbands; sons who fail in their duties; working partners who behave badly to the moneyed partner, and many others. All these, even though they have a credit for good deeds, must pass through the misery of every ward. On the stage, two torments are shown, a man being simmered in an oil-kettle, and another having the intestines pulled out.

Court IV is under the jurisdiction of King Wu Kuan. This Court is 500 li (Chinese miles) in compass, being subdivided into sixteen wards, as follows: -The first is a pool beneath a high precipice where the shades of the wicked are hung up, and water is continually poured over them. In the second, they are made to kneel on chains and bamboo splinters. In the third, their hands are scalded with boiling water. In 
the fourth, their hands swell and stream with perspiration and blood. In the fifth, their sinews are cut, and their bones pulled out. In the sixth, their shoulders are pricked with a trident, and the skin is rubbed with a hard iron brush. In the seventh, holes are bored in their flesh. In the eighth, they are made to sit upon spikes. In the ninth, they wear iron clothes. In the tenth, they are crushed under heavy pieces of wood, stone, earth, or tiles. In the eleventh, their eyes are plucked out. In the twelfth, their mouths are choked with dust. In the thirteenth, they are perpetually dosed with abominable drugs. In the fourteenth, they are slipping on oiled beans and constantly falling down. In the fifteenth, their lips are painfully pricked. In the sixteenth, their bodies are buried under gravel, with the head projecting above it.

To this purgatory are condemned those who cheated the customs and evaded taxes; those who repudiated their rent, used weighted scales, sold sham medicines, made base coin, got deeply in debt, sold silks and satins with a false gloss on them; those who did not make way for the cripples, old and young; those who stole bricks from walls as they passed by, or oil and candles from lamps; those who allowed their mules and ponies to be a nuisance to other people; those who destroyed their neighbor's crops or his walls and fences, and many others.

The tortures shown on the stage are the fiery iron bed on which a woman is being roasted, and a stake to which a female culprit is tied to have her eyes plucked out.

Court V (Case 3 ) is under the jurisdiction of King Yen-lo; that is, the ancient Indian god of death, Yama. It is $500 \mathrm{li}$ (Chinese miles) in compass, being sub- 



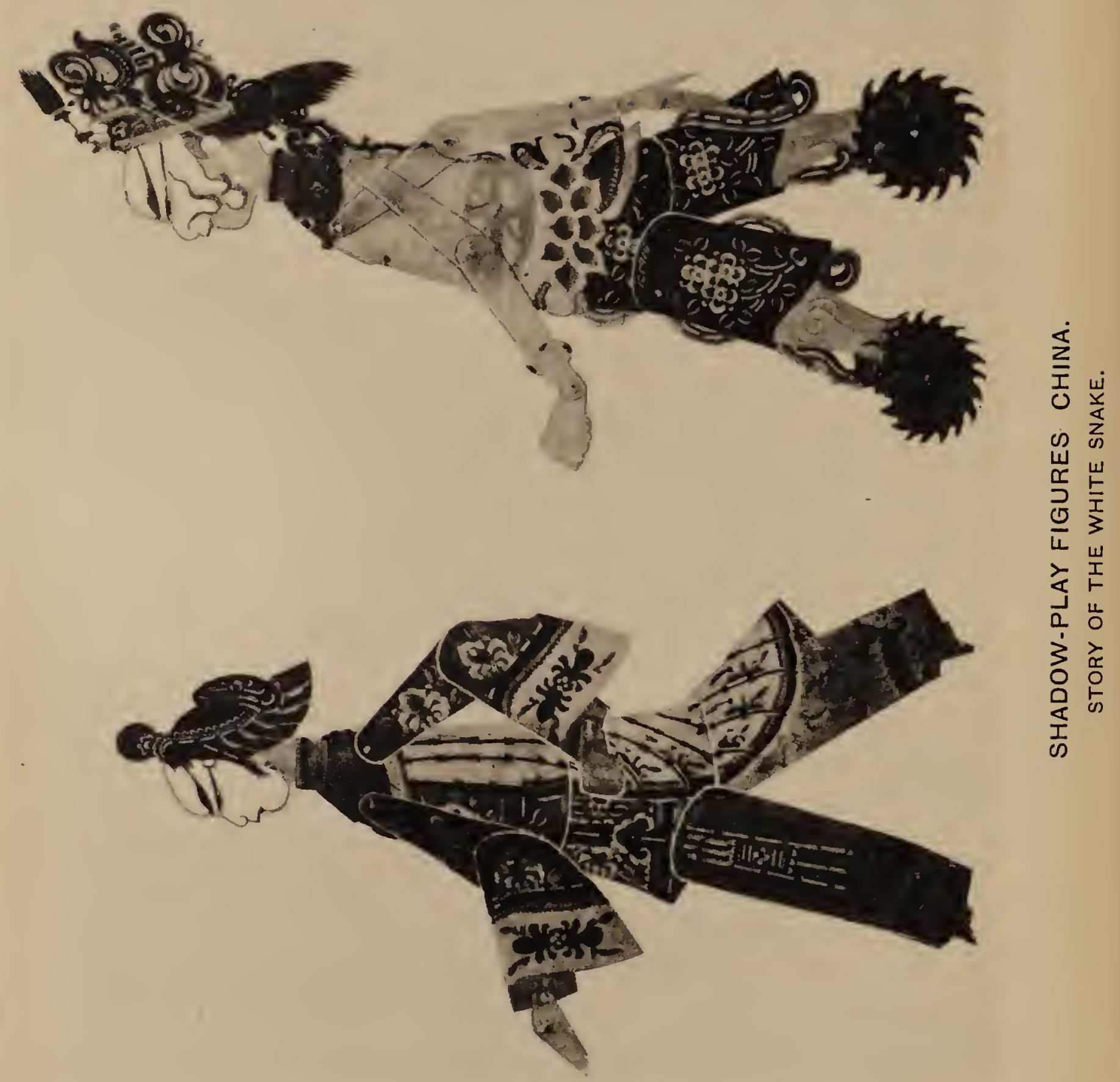


divided into sixteen wards, as follows:-In the first are sceptics and those who do not worship. In the second, those who have destroyed life or hurt living creatures. The punishment in both is pulling out of the heart. In the third are those who have not fulfilled their vows. In the fourth are believers in heretical doctrines, magicians, sorcerers, and those using evil charms to prolong life. In the fifth are those who deceived the good, tyrannized over the weak, but cringed to the strong, also those who openly wished for another's death. In the sixth are those who tried to thrust their misfortunes on to other people's shoulders. In the seventh are those who committed adultery. In the eighth are those who injured others with a view to personal profit. In the ninth are those who are niggardly and refused to help others in distress. In the tenth, are those who committed theft and involved the innocent. In the eleventh are those who forgot kindness or sought revenge. In the twelfth are those guilty of conspiracy, who stirred up others to quarrel, keeping themselves out of harm's way. In the thirteenth are those who spread false reports or enticed to wickedness. In the fourteenth are those who were fond of brawling and fighting, and implicated others. In the fifteenth are those who envied and hated the virtuous and wise. In the sixteenth are those who are lost in vice, evilspeakers, slanderers, impenitent and stubborn people, and such like persons.

All those shades who come before this Court have already suffered long tortures in the previous four Courts, whence, if they are hardened sinners, they are passed on after seven days to this Court, where they are subjected to a further process of purification. On the stage are shown the tortures of the "knife-hill" (a hill 
bristling with knives on which the delinquents constantly climbing up and down become impaled) and cutting the tongue. Attention is called especially to the mask of the "Devil with the Big Head," a humorous caricature of the stage.

Court VI (Case 3) is under the jurisdiction of King Pien Ch'eng. It extends 500 li (Chinese miles) in circumference, and around it are sixteen wards, as follows:-In the first, the shades of the wicked are made to kneel for long periods on iron shot. In the second, they are immersed up to their necks in filth. In the third, they are pounded till the blood runs out. In the fourth, their mouths are opened with iron pincers and filled with needles. In the fifth they are bitten by rats. In the sixth, they are enclosed in a net of thorns and preyed on by locusts. In the seventh, they are crushed to a jelly in a mortar. In the eighth, their skin is lacerated, and they are beaten on the raw. In the ninth, their throats are choked with fire. In the tenth, their skin is blistered with burning mulberry-wood. In the eleventh, they are subjected to fetid odors. In the twelfth, they are butted by oxen and kicked by horses. In the thirteenth, their hearts are scratched. In the fourteenth, their heads are rubbed till their skulls come off. In the fifteenth, they are chopped in two at the waist. In the sixteenth, they are flayed, their skin being rolled up into spills.

In this Court will be found those discontented ones who rail against Heaven and revile Earth, who are always finding fault with wind, thunder, heat, cold, fine weather, or rain; those who steal the gold from the inside or scrape the gilding from the outside of Buddhist images; those who show no respect for written paper by destroying it, who throw down rubbish near a 
temple, who use filthy kitchens and stoves for preparing the sacrificial meats, who do not abstain from meat; those who have in their possession blasphemous or obscene books and do not destroy them, who tear books teaching man to be good; those who embroider the Svastika (because it is the symbol on Buddha's heart) on fancy work; those who secretly wear clothes adorned with the dragon and the phœnix (emblems of imperial dignity) ; those who buy up grain and corner it until the price is exorbitantly high. Persons guilty of the above crimes, if they will abstain from animal food on the third day of the eighth month and register a vow from that date to sin no more, and on four other days practise abstinence, vowing moreover to exert themselves to convert others, shall escape the bitterness and torments of all the wards of the Sixth Court. On the stage is shown the torture of a culprit being hacked in a chaff-cutter.

The majestic God T'ai Shan, the powerful spirit of the sacred mountain of the same name in Shan-tung, reigns at the bottom of the great Ocean, away to the northwest, below the Wu-tsiao rock. His realm represents the seventh Court of Purgatory and measures $500 \mathrm{li}$ (Chinese miles) in circumference, being subdivided into sixteen wards, as follows:-In the first, the shades of the wicked are made to swallow their own blood. In the second, their legs are pierced and thrust into a fiery pit. In the third, their chests are cut open. In the fourth, their hair is torn with iron combs. In the fifth, dogs gnaw their bones. In the sixth, large stones are placed on their heads. In the seventh, their skulls are split open. In the eighth, they are scorched by fire and pursued by dogs. In the ninth, they are flayed, carrying off their skins. In the tenth, they are 
pecked by huge birds. In the eleventh, they are hung up and beaten on the feet. In the twelfth, their tongues are pulled out, and their jaws bored. In the thirteenth, they are disemboweled. In the fourteenth, they are trampled on by mules and bitten by badgers. In the fifteenth, their fingers are burnt with hot iron. In the sixteenth, they are boiled in oil.

To this Court will be condemned those who practise swallowing certain drugs, in order to procure immortality; those who spend more than is wise upon wine; those who kidnap human beings for sale; those who steal clothes and ornaments from coffins; those who break up the bones of a corpse for medicine; those who separate people from their relatives; those who sell the girl brought up in their house to be their son's wife; those who conspire to cheat others in gambling; those who unduly beat and injure their servants; those guilty of extortion, those disobeying their elders, talking at random and going back on their word, and those stirring up others to quarrel and fight. Whoever on the 27th of the third moon, fasting and facing toward the north, will register a vow to pray and repent, and to publish the whole text of the Buddhist Eschatology (a popular tract in which the Courts and torments are illustrated and described) for the enlightenment of mankind, may escape the bitterness of this Seventh Court.

On the stage is shown the torture of sawing a culprit in two. Additional features are two delinquents with hands chained to their backs and tied to a stake, and the figure of a culprit wearing the cangue or pillory around neck and hands. On the cangue, the words are written, "Be it known to all that he is condemned to carry the cangue and wear a lock,-Depart- 



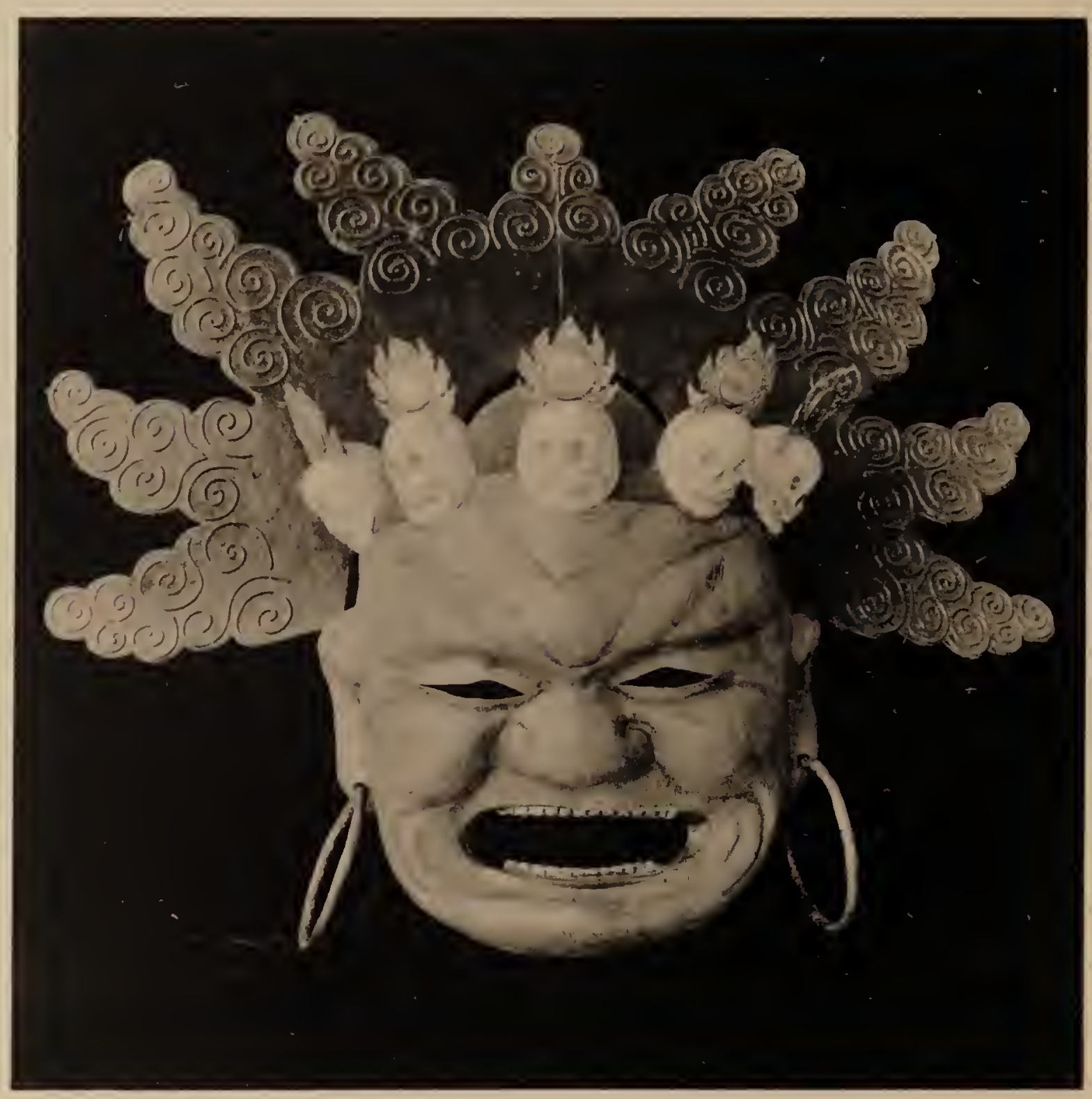

THE TIBETAN MYSTERY-PLAY.

MASK OF ONE OF THE SIX MAHĀKĀLA, DEFENDERS OF THE LAMAIST FAITH. Case 12, Bottom. 
ment of the Dark Regions." The wearing of the wooden collar is a frequent punishment in China, particularly for such offences as petty larceny, etc., which are duly inscribed thereon. The time for which it may be imposed, and its weight (up to a limit of thirty pounds), are regulated by law. It is generally taken off at night; during the day while the wearer is exposed to the public eye on the market, he must be fed by friends. The word cangue used in the East is derived from Portuguese canga ("an ox-yoke," or "porter's yoke for carrying burdens"). The practice was introduced into China by the Tungusian dynasty of Wei in the fifth century.

Court VIII is ruled by King Ping Teng. It is 500 li (miles) in compass, and subdivided into sixteen wards:-In the first, the shades of the wicked are rolled down mountains and overrun by carts. In the second, they are shut up and suffocated in iron tanks. In the third, their flesh is minced. In the fourth, their noses, eyes, and mouths are stopped up. In the fifth, their tongues and uvulas are cut off. In the sixth, they are imprisoned in an iron cage. In the seventh, their extremities are broken. In the eighth, their intestines are cut out. In the ninth, the marrow of their bones is cauterized. In the tenth, their bowels are scratched. In the eleventh, they are inwardly burnt with fire. In the twelfth, they are disemboweled. In the thirteenth, their chests are torn open. In the fourteenth, their skulls are split, and their teeth dragged out. In the fifteenth, their bodies are lacerated. In the sixteenth, they are pricked with tridents and pitchforks. Those who are unfilial, who neglect their parents or fail to bury them after their death, who subject their parents to fright, sorrow, or anxiety, 
-if they do not quickly repent of their former sins, the God of the Domestic Hearth will report their misdoings and gradually deprive them of what prosperity they may be enjoying. Those who indulge in magic and sorcery will, after death, when they have been tortured in the other Courts, be brought to this Court, and dragged backwards to be tormented, and in time they shall be born again as animals. But those who believe in the doctrine of Buddhist eschatology and make a vow of repentance, repeating it every night and morning to the God of the Hearth, shall receive from him, at their death, one of the three words "obedient, willing, or penitent" traced on their foreheads. They shall escape half the punishment from the First to the Seventh Court, escaping the Eighth Court altogether, to be finally reborn from the Tenth Court among mankind as before.

On the stage is shown the torture of being suspended from a scale.

Court IX is under the jurisdiction of King Tu Shi. This Court corresponds to the last of the eight hot Infernos of Brahmanism (called in Sanskrit, Avici), where the culprits die, and are reborn without interruption, but with the hope of final redemption. It is a vast, circular place, securely enclosed by an iron net, and subdivided into sixteen wards, as follows:-In the first, the shades of the wicked have their bones beaten and their bodies scorched. In the second, their muscles are drawn out, and their bones beaten. In the third, crows peck out their hearts and livers. In the fourth, dogs devour their intestines and lungs. In the fifth, they are hurled into a cauldron of boiling oil. In the sixth, their heads are crushed in a frame, and their tongues and teeth are drawn out. In the seventh, their 
brains are taken out, and their skulls filled with worms. In the eighth, their heads are steamed, and their brains scraped. In the ninth, they are dragged about by sheep till they drop to pieces. In the tenth, they are squeezed in a wooden press and pricked on the head. In the eleventh, their hearts are ground in a mill. In the twelfth, their entire bodies are scalded by dripping boiling water. In the thirteenth, they are stung by wasps. In the fourteenth, they are tortured by ants and venomous insects; they are then stewed, and finally wrung out like clothes. In the fifteenth, they are stung by scorpions. In the sixteenth, they are tortured by poisonous snakes entering their nostrils.

All who on earth committed one of the ten great crimes, and deserved either the lingering death, decapitation, or strangulation, shall, after passing through the tortures of the previous Courts, be brought to this Court, together with those guilty of arson, of producing indecent pictures or obscene books, of making stupefying drugs, and of other disgraceful acts. Then, if it be found that, hearkening to the words of the Buddhist eschatology, they subsequently destroyed the printingblocks of these books, burnt their prescriptions, and ceased practising the magical art, they shall escape the punishments of this Court and be passed on to the Tenth Court, thence to be born again among human beings. But those who will not repent shall suffer in intensified form all the tortures from the Second to the Eighth Court. In this Court, they shall be bound to a hollow copper pillar, clasping their hands and feet around it. Then the pillar will be heated and burn their hearts and livers. On the stage, the torture of this fiery copper pillar is shown.

A noteworthy figure in this Court is that of a 
hungry shade. It is a man who died without issue, and consequently has nobody to feed him after death with the prescribed ancestral sacrifices. In consequence he is vagabonding in the other world as a lonesome and starving shade, eking out a living by begging for alms. Such figures are on view in the temples as a warning to childless people, and exhorting them not to commit race-suicide.

Court $\mathrm{X}$ is under the jurisdiction of King Chuan Lun; that is, "the king turning the wheel of the law." He has charge over the six bridges corresponding to six forms of re-birth, of which the Golden and Silver Bridges are shown here. He examines all shades before they are allowed to pass over, and controls the new form of existence which they are allowed to assume; for at this point they have reached the end of their long migrations. This Court is therefore called "the Wheel of Transformation." Originally a figurative expression, later it was popularly conceived as something real, the belief being entertained that the souls are passing round in a huge Wheel of Fate, where their next form of life, the duration of their existence, and the place of their abode are determined. The place where the Wheel of Fate revolves is many miles in extent, enclosed on all sides by an iron palisade. Within are 81 subdivisions, each of which has its particular officers and magisterial appointments. Beyond the palisade, there is a labyrinth of 108,000 paths leading by direct and circuitous routes back to earth. Inside, it is as dark as pitch, and through it pass the-spirits of priest and layman alike. But, to one who looks from the outside, everything is visible as clear as crystal, and all the attendants who guard the place have the faces and features that they had at their birth. These at- 
tendants are chosen from virtuous people who in life were noted for filial piety or friendship, and are sent here to look after the working of the wheel. If for a period of five years they make no mistake, they are promoted to a higher office; but if found to be lazy or careless, they are reported to the Judge for punishment.

Those who in life have been unfilial or have destroyed life, after undergoing tortures in the various Courts, are brought here and beaten to death with peach twigs. With changed heads, they are turned out into the labyrinth to proceed by the path which ends in their re-birth as an animal. After myriads of years, animals may resume their original shapes. Whoever will not destroy life during their existences may be born among human beings as a reward.

The main importance of this Court lies in the Terrace of Oblivion to which all shades must proceed. There is a cliff in this region on which the following lines are written: "To be a man is easy, but to act up to one's responsibilities as such is hard. Yet to be a man once again is harder still. For those who would be born again in some happy state there is no great difficulty; all that is required is to keep mouth and heart in harmony."

There are six bridges in the other world, of gold, silver, jade, stone, wood, and planks, over which all souls must pass. The shades of good people, after having been passed on from the First to the Tenth Court, are examined by the Judge of the latter Court, and according to their merits are allowed to cross one of these bridges in order to be sent back to earth. There, they will be reborn as they have deserved by their conduct in a previous existence, as men, women, old, young, high, low, rich, or poor. A list of the names 
of all people passing the bridges is kept and forwarded monthly by the Judge of the Tenth Court to the Judge of the First Court for transmission to Feng-tu, the capital city of the Infernal Regions. An official and his wife are crossing the bridges shown in the play.

A remarkable figure in this Purgatory is presented by the mask of Mother Mong, whose story is as follows: Mother Mong was born at the time of the Earlier Han dynasty. In her childhood she studied books of the Confucian school; when she grew up, she chanted the liturgies of Buddha. She exhorted mankind to desist from taking life and become vegetarians. At eightyone years of age her hair was white, and her complexion like a child's. She retired to the hills and lived as a recluse until the Later Han. Because certain evildoers, under the pretext of a knowledge of past existences, used to beguile women by pretending to have been their husbands in a former life, the Judge of the Tenth Court commissioned her to build the Terrace of Oblivion, and appointed her as guardian. It was arranged that all shades who had been sentenced in the Ten Courts to return in various conditions to earth should first be dosed by her with a decoction of herbs. Thus they forgot everything that had previously happened to them. Good spirits who go back into the world will have their senses of sight, hearing, smell, and taste very much increased in power, and their constitution generally will be improved. Evil spirits will experience the exact contrary of this, in retribution of previous sins. The pot on a red-lacquered stand is the one in which the drink of oblivion is boiled. 


\section{THE LION-DANCE, CHINA}

The lion-dancers first appeared in China under the T'ang dynasty (A.D. 618-906), and made their début at the court of the kings of Tibet about the same time. The lion-dancer represents a form of the Indian mime or burlesque juggler, who originally exhibited tame lions and trained monkeys, wandering from place to place, entertaining crowds at fairs and religious festivals. Along the high roads of Shen-si Province in northern China are still to be seen numerous square pillars surmounted by figures of lions, monkeys, and stage-fools. In some cases the monkey squats on the lion's back, in others it is the fool stretching out his hands into the animal's jaws, who sits astride the lion's back. He wears the characteristic, spacious, conical fool's cap, the tip of which falls down in front, his countenance expressing a somewhat melancholy, but humorous good nature. The mimes, at first, simply covered their faces with a lion mask (as shown in Case 11 ), and it is an interesting coincidence that the European harlequin also frequently appears with the mask of the lion; for the lion had developed into the emblem of the buffoon.

Live lions were not obtainable in China and Tibet, and as their transportation from India was a costly matter, the strolling mimes soon hit upon the expedient of representing the lion's body by a covering of cloth and using two men instead of one,-one carrying the head; the other, the hind portion; the trousers of each forming the animal's feet (Case 5). Buddhists recognize the lion as the emblem of Buddha, who in the sacred texts is referred to as "he with the lion's voice." The lion is regarded as the protector of his religion; hence huge statues of lions are generally to be found 
in front of Buddhistic temples. In this way the liondance came to be looked upon also as a demon-expelling ceremony. In Peking companies of acrobats have been organized to cultivate this specialty. The blue and yellow lions perform a contra-dance, displaying an astounding skill and agility; the eyeballs, tongue, jaws, ears, and tail in rapid motion, while the bells of the neck-collars tinkle to the accompaniment of gongs. The lion being credited with a fondness of playing with a ball, the main feature of the performance is the pursuit by the lions of an enormous ball which is thrown in front of them or across their path. They will even leap on to the roof of a one-storied house, and jump down from there into the courtyard.

\section{IMPERIAL PLAY, CHINA}

On the occasion of a birthday or wedding, it is customary in China to invite a company of actors to give a performance in the family circle. Such private entertainments are always introduced by a dramatic scene of symbolical and allegorical character in which, for example, all the benevolent genii of Heaven appear on the stage to convey their good wishes to the person honored and the guests, and bestow on them their blessings and super-natural gifts, above all, those of long life, wealth, and progeny. The masks here on view (Cases 6-7) are those of a pageant formerly given in honor of an emperor's birthday, and are of especial interest, as several mythological groups, taken from the popular pantheon, appear on the stage to congratulate the emperor and invoke blessings upon him. The following are worthy of special mention: 
The Twenty-Eight Patriarchs are a series of venerable priests, who, as fathers of the church, pursued the mission of propagating the doctrine of Buddha and preserving its original purity. They were all natives of India, some of them contemporaries of Buddha, others living in different periods down to the sixth century A.D.

The Buddhist patriarchs are followed by the Gods of the Twenty-Eight Lunar Mansions. The lunar mansions form a zodiac consisting of twenty-eight constellations near the ecliptic. The number 28 is connected with the period of the moon's revolutions. This system is found, not only among the Chinese, but also among the Indians and Arabs. In fact, the astronomical lore of the great civilized nations of Asia appears to have had a common foundation. The Chinese series of the lunar mansions was well established in the third century B.c. Each mask is characterized by the figure of the animal with which its lunar mansion is associated, and it personifies "the official" presiding over the constellation. On the individual labels the names of the lunar mansions are given in Chinese and Sanskrit, the names of the animal and the element to which they belong, the corresponding constellation, and symbolism connected with it, being added.

Next appear on the stage the Dragon Kings of the Four Seas, corresponding to the Nāga kings of Indian mythology, who are conceived as serpents, and are believed to be the guardian spirits of the waters. In China they were associated with the dragon, a rainsending deity whose abode is in the ocean and in the clouds. Next follow eight female fairies, viz.; the fairy of the pear blossoms, the fairy of the cinnamon blossoms, the fairy of the lotus, the fairy of the spring 
breeze, the fairy of the thousand flowers, the fairy of the hundred flowers, the fairy of the ten thousand flowers, and the fairy of the autumn moon; together with the Eight Immortals accompanied by the gods of longevity, luck, and prosperity, as well as the twin genii symbolizing harmony and union.

The procession is closed by a group of twenty-one masks representing the principal casts of the great mythological romance Fung shen yen $i$. This is a kind of wonder book with a hundred long chapters, the plot centering around the adventures of $\mathrm{Wu}$ Wang, the founder of the Chou dynasty (1122 B.C.), in his contest with Chou-sin (1154-23 B.C.), the last ruler of the house of Shang, notorious for his tyranny and cruelty. $\mathrm{Wu}$ Wang is assisted in this national war by a countless host of saints, magicians, and spirits, and finally overcomes all his enemies. The prominent heroes fighting on both sides are promoted to the ranks of gods by the new ruler (the title Feng shen means "investiture with the dignity of a spirit"). The many hundreds of legends and episodes, of which this complex romance is composed, reflect a strange medley of Taoist and Buddhist motives and beliefs, characteristic of that syncretism and process of assimilation prevalent in the popular religion, which is neither pure Buddhism nor pure Taoism, but a blending of these two elements reinterpreted in a fantastic manner. These twenty-one masks are as follows:-

1. Kiang Tse-ya (illustrated). He was the chief counselor to Wu Wang, founder of the Chou dynasty, serving him and his son for twenty years and aiding them in consolidating the empire. The emperor first met him when he was a man of eighty years of age, and discovered him in the act of fishing with a straight 
iron rod instead of a hook, thus offering as little inducement as possible to the fishes, which, attracted by his virtue, readily allowed themselves to be caught, in order to satisfy the needs of this wise and contented angler. His reputation among the present-day people rests on the authority which he is believed to have exercised over the spirits of the unseen universe. The mere phrase "Mr. Kiang is here!" written on the door of a house is a sufficient means of frightening away any evil demon.

2. K'iung Siao, a nature goddess residing on Three Fairies Island (San sien tao), who, with the two following fairies, forms a triad.

3. Pi Siao, a nature goddess, inhabiting the same island.

4. Yün Siao, a nature goddess of the same island. She is the owner of a pair of magic scissors which resemble two dragons, contain the essence of heaven and earth, sun and moon, and are capable of cutting gods and men in two.

5. Tao-hing T'ien-tsun, a saint residing in the cave Yü-wu ("Jade Room") on Mount Kin-ting ("Golden Summit"). He is in the possession of powerful charms, by means of which he provides the starving army of Wu Wang with grain, and finally takes an active part in his battles against Chou-sin.

6. P'u-hien Chen-jen, the Bodhisatva Samantabhadra as a Taoist conception, residing in the Cave of the White Crane on the Mountain of Nine Palaces. The Taoist pantheon has borrowed much from Buddhism, and has adopted numerous Buddhist deities with slight alterations of name and form. This saint assisted Wu Wang in his struggle, availing himself of a white elephant as riding-animal. 
7. Wen-shu Kuang-fa T'ien-tsun, the Bodhisatva Manjuçri as a Taoist conception, residing in the Cave of Fleecy Clouds (Yün-siao) on the Mountain of Five Dragons (Wu-lung). He belongs to the company of saints aiding $\mathrm{Wu}$ Wang in his national war, availing himself of a lion as his riding-animal.

8. Huang T'ien-hua, son of Huang Fei-hu (cf. above, p. 14), general of Chou-sin, and like all characters of this story, is an adept in magic. He revives his slain father, fights battles with the magical "firedragon club," is killed, restored to life, suffers death again, and is finally deified.

9. Hung Kin, an officer of the emperor Chou-sin, who takes advantage in battle of a wonderful black flag which is capable of being transformed into a gate, thus deceiving his adversaries. He is vanquished by a goddess, daughter of Si Wang $\mathrm{Mu}$, who renders herself invisible by means of a white flag. Hung Kin changes earth into ocean, the goddess follows him on the back of a whale, and binds him with the dragon-fettering chain. He is then sentenced to marry her.

10. Chao Kung-ming (illustrated), a powerful magician residing in the cave Lo-fou on the sacred Mount O-mei in Se-ch'uan. His riding-animal is a tame tiger capable of carrying him through the air. $\mathrm{He}$ defeats his adversaries by means of magical weapons.

11. Ts'ing-su Tao-te T'ien-tsun, a saint residing in the cave Tse-yang on the Mount with Green Summit ( Ts'ing fung). He rescues the blinded Yang Jen, and by virtue of his magical power, produces new eyes on his hands (see No. 19). He dispatches Huang T'ienhua to restore his slain father to life, and to assist him (see No. 8).

12. Ts'e Hang Tao-jen, a saint residing in the cave 
Lo-kia on the Isle of $\mathrm{P}^{\prime} \mathrm{u}$-t'o in the Chusan Archipelago. $\mathrm{He}$ is a Taoist conception of the Buddhist deity Kuanyin, his name signifying "the Merciful Barge," because Kuan-yin is believed to convey departed spirits from the ills of mortality to a state of bliss. He aids Wu Wang in his national war.

13. Yün Chung-tse, a magician, who is in possession of a magic mirror capable of capturing demons. He brings to Wu Wang a magic sword to expel a fox spirit, and finally takes part in the battles himself.

14. T'ai-yi Chen-jen, a saint residing in the cave of Gold Lustre (Kin-kuang) on Mount K'ien-yüan, and a supporter of Wu Wang in his holy war against the tyrant Chou-sin.

15. Huang-lung Chen-jen, "The Saint of the Yellow Dragon," residing in the cave Ma-ku on Mount Erh-sien, and fighting in the ranks of Wu Wang.

16. Yü-ting Chen-jen, a saint residing in the cave Kin-hia on Mount Yü-tsüan, and who supports Wu Wang.

17. Chi-tsing-tse, a saint living in the cave of Fleecy Clouds (Yün-siao) on Mount T'ai-hua. He restores a slain hero to life and takes part in Wu Wang's battles.

18. T'u Hing-sun, a dwarf, the son of the goddess Si Wang $\mathrm{Mu}$, who excels in healing wounds.

19. Yang Jen, who exhorted the emperor Chousin to abandon his evil ways, and whose eyes were pulled out as punishment. By means of a charm, eyes were produced on his hands, with which he was able to perceive all things in heaven and earth.

20. Kuang Ch'eng-tse is a Taoist priest, residing in the cave T'ao-yüan on the Mountain of Nine Fairies, his weapon being a magic seal which turns heaven 
upside down. He is believed to be a former incarnation of the philosopher Lao-tse, who himself is a purely legendary figure in popular Taoism.

21. Kiü Liu-sun, a Taoist saint believed to be an incarnation of Çākyamuni Buddha.

Readers in quest of more information on this subject and other stories alluded to in these pages are referred to a recent work by E. T. C. Werner, "Myths and Legends of China" (London, 1922).

\section{THE SHADOW-PLAY, CHINA}

At the present time in China, there are, broadly speaking, two popular theatrical pastimes,-the puppet-play or marionettes, and the shadow-play. The scenarios given in these two representations are now identical, being both derived from the literary drama of the legitimate stage. Marionettes and shadow-play make their appeal to the popular taste by having their plots recited in the living vernacular, while the repertoire of the stage in general adopts the literary language which is intelligible only to the educated classes. Despite this modern uniformity, marionettes and shadow-play have in China a very different history.

The shadow-play is, without doubt, indigenous to China. The first mention is made of it in the Historical Annals of Se-ma Ts'ien and relates to the year 121 B.C. This historian narrates the following anecdote. Wu-ti, an emperor of the Han dynasty, lost one of his favorite wives, and was obsessed by a great desire to see her again. One day a magician appeared at court who was able to throw her shadow on a transparent screen. 
This story is symbolic of the general idea underlying these early primitive shadow performances. The shadow figures, indeed, were the shadows or souls of the departed, summoned back into the world by the art of professional magicians. This conception of ancestors as shadow-souls is so characteristically Chinese, that it goes far to prove the priority of this performance in China. Its inception, therefore, is purely religious and traceable to spiritistic seances.

During the middle ages a new element was introduced into the subject of these plays when the people became largely attracted by the romantic stories of the Three Kingdoms. In the third century of our era, the country was divided into three states which were at war with one another. Errant knights roamed over the country who chivalrously espoused the cause of the weak, the innocent, and the oppressed. The history of this romantic age was subsequently woven into a semihistoric romance composed of numerous stories which were recited on the public squares by professional story-tellers. Under the Sung dynasty, these storytellers illustrated their narratives by means of transparencies in which figures represented the principal heroes of the cycle. Later, under the Mongol dynasty, when representatives of all nations flocked to the capital, Peking, the shadow-play attracted wide attention; and owing to the military and political expansion of the Mongols all over Asia, it was conveyed to the Persians, the Arabs, and the Turks. The famous Persian historian Rashid-eddin, who died in 1318, records a very interesting story. At the Persian court of the Mongol emperor, Ogotai, the son and successor of the conqueror Chinggis Khan, actors from China performed behind a curtain wonderful plays in which 
the types of various nations were represented, among them an old Mohammedan with a white beard and a turban tied around his head and ending in a horse's tail. In the first part of the fifteenth century we find that the shadow-play had established itself as a favorite pastime at the court of Sultan Saladin in Egypt. The Turkish conqueror, Selim, was the first to take a shadow-player from Cairo to Constantinople. The performance seems to have arrived at Constantinople by two routes,-from Egypt, and from the interior of Asia by way of Turkestan and Persia, as we still find it in vogue at Khokand, Tashkend, Khiwa, Bukhara, and Samarkand. In Turkish literature the shadow-play appears first in the seventeenth century.

It did not penetrate to France until 1767. The French name "ombres chinoises" is a reminder of its Chinese origin, and is traceable to the famous work "Description of the Chinese Empire" by the Jesuit Father Du Halde, who was the first European author to call attention to this pastime in China. The performances given in Paris found their way to London in June, 1776. On Goethe's birthday, 28th of August, 1781, "Minerva's Birth, Life and Deeds," and on the 24th of November "The Judgment of Midas," were given by means of Chinese shadow figures. In "The Fair at Plundersweilen" (1774) Goethe brings a shadow-player on the stage.

While the shadow-play was originally of a religious character, and gradually assumed the function of a mere entertainment, the opposite of such a development may be observed in the history of marionettes. Marionettes cannot be traced in the times of early antiquity in China. They are mentioned for the first time in the records of the T'ang dynasty about the year A.D. 630 , 


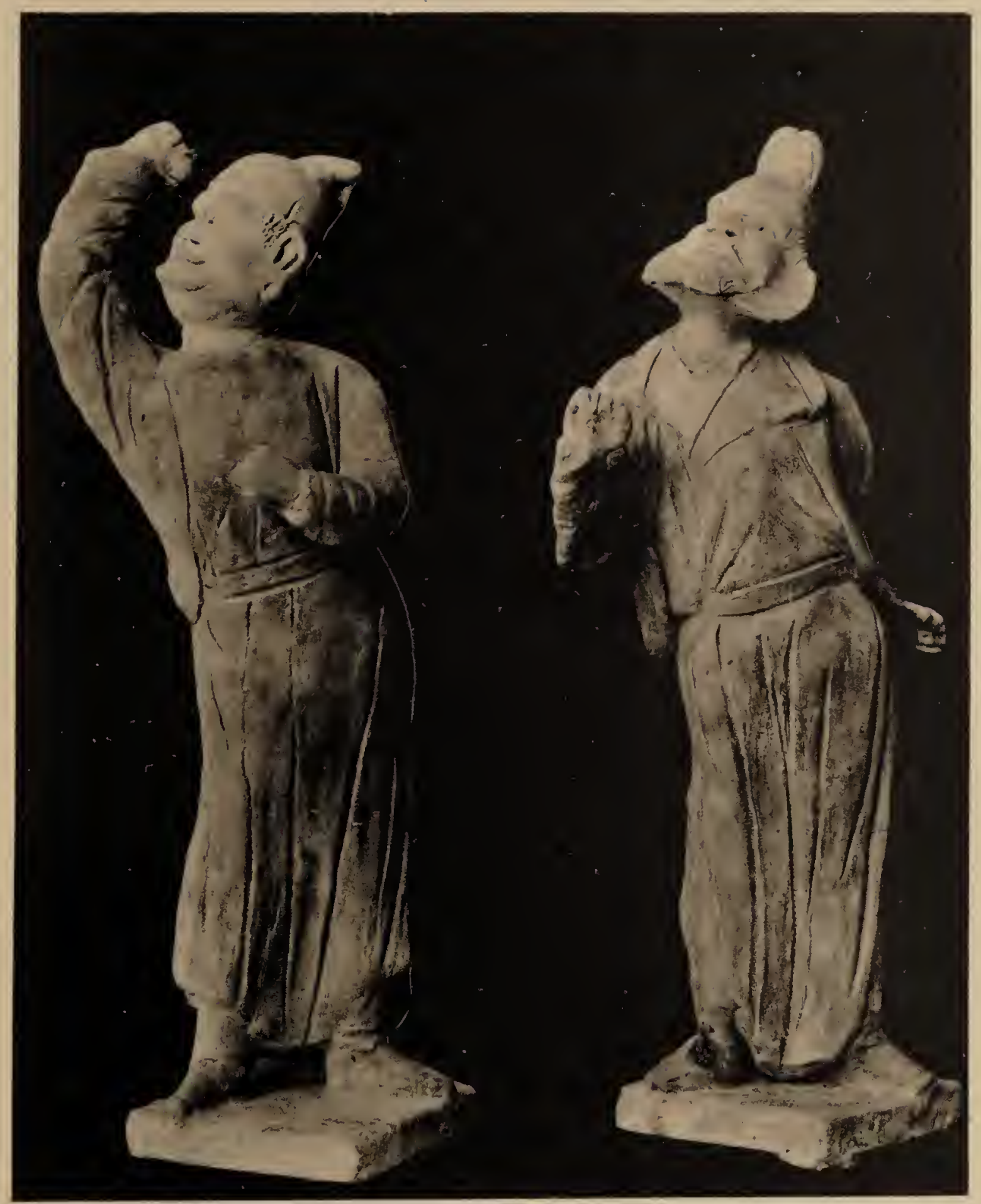

BURIAL CLAY FIGURES OF ACTORS FROM KUCHA (p. 39). CHINA, T'ANG PERIOD (A.D. 618-906). 

when the capital of China was Ch'ang-an. At that time Turkestan was subject to China, and the capital swarmed with jugglers, mimes, and actors, hailing from Kucha in eastern Turkestan. Two clay figures representing such actors and interred in a grave for the entertainment of the dead are here illustrated. It is on record that these actors also brought performances given by means of puppets, and at the same time transmitted the Turkish name for the latter, kuikla (modern Chinese $k^{\prime} w e i$-lei). This word, however, is not of Turkish origin, but is traced to mediæval Greek. From Byzance it spread to the Slavs, and the Slavs handed it on to the Turkish tribes. It is still the general word designating a puppet in all Slavic and Turkish languages, as well as in Gipsy. This migration of the word bears out the fact, confirmed by other evidence, that the idea of using puppets for dramatic plays, as far as we know, first emanated from Greece. Numerous figures of marionettes have been discovered in ancient Egypt, Greece, and Rome. In their construction and method of manipulation these classic marionettes are identical with those still made in China. The ancient Greek name means "puppets suspended from strings or threads," and we meet exactly the same designation in corresponding translations in Sanskrit, Chinese, and Japanese.

Originally the puppet-play had no religious significance whatever. It was purely a pastime, chiefly for the entertainment of women and children. In Asia it rapidly achieved popularity, because respectable women were barred from the public theatre. Indeed, it seems possible that the puppet-show was suggested by the idea of reproducing a stage in miniature, for the purpose of bringing the theatre into the home for 
the entertainment of the family. It is still customary in China for the itinerant showmen to respond to calls to give performances in the courtyards of private houses. Curiously enough, the development of marionettes in China was such that they were turned to religious purposes at an early date. There are many accounts to the effect that during the Sung and Ming periods (960-1643) performances were given with marionettes after funerals, in honor of the deceased, and even scenes taken from the career of the dead were introduced to honor their memory.

In the shadow-play the figures are flat and ingeniously cut out of parchment, usually ox or sheep skin evenly colored and varnished on both sides. When held against the light they are transparent. A screen of white gauze (Case 8), lighted by means of oil lamps from behind, is stretched between two poles; and the figures, held by wires stuck into bamboo or reed handles, are skilfully manipulated behind the screen. Head, arms, and legs being cut out separately, great agility of motion is assured. Some aver that the shadow-play is the most realistic and picturesque of all the popular performances, as the regular stage (much on the same level as the Shakespearian theatre) is almost lacking in scenery, while all the stage requisites, as sea, clouds, rivers, gardens, mountains, palaces, temples, courts, sedan chairs, boats, gods, demons, and monsters are well represented in the shadow performance.

The performance is always accompanied by a small orchestra, while the various roles are recited by an operator seated behind the curtain. The plots are taken from Buddhist and Taoist lore or incidents in the history of China. The subjects, however, in which 


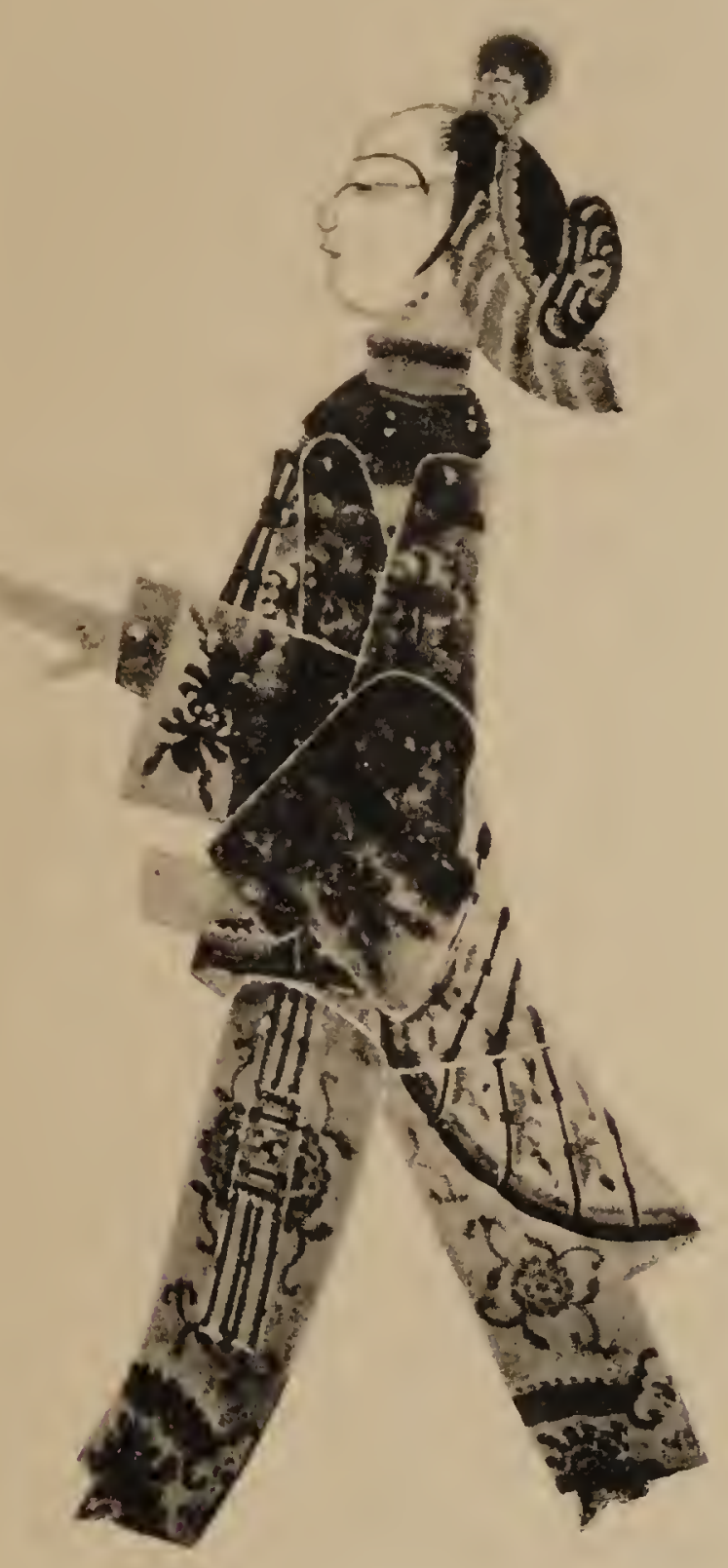


the entertainment of the family. It is still customary in China for the itinerant showmen to respond to calls to give performances in the courtyards of private houses. Curiously enough, the development of marionettes in China was such that they were turned to religious purposes at an early date. There are many accounts to the effect that during the Sung and Ming periods (960-1643) performances were given with marionettes after funerals, in honor of the deceased, and even scenes taken from the career of the dead were introduced to honor their memory.

In the shadow-play the figures are flat and ingeniously cut out of parchment, usually ox or sheep skin evenly colored and varnished on both sides. When held against the light they are transparent. A screen of white gauze (Case 8), lighted by means of oil lamps from behind, is stretched between two poles; and the figures, held by wires stuck into bamboo or reed handles, are skilfully manipulated behind the screen. Head, arms, and legs being cut out separately, great agility of motion is assured. Some aver that the shadow-play is the most realistic and picturesque of all the popular performances, as the regular stage (much on the same level as the Shakespearian theatre) is almost lacking in scenery, while all the stage requisites, as sea, clouds, rivers, gardens, mountains, palaces, temples, courts, sedan chairs, boats, gods, demons, and monsters are well represented in the shadow performance.

The performance is always accompanied by a small orchestra, while the various roles are recited by an operator seated behind the curtain. The plots are taken from Buddhist and Taoist lore or incidents in the history of China. The subjects, however, in which 

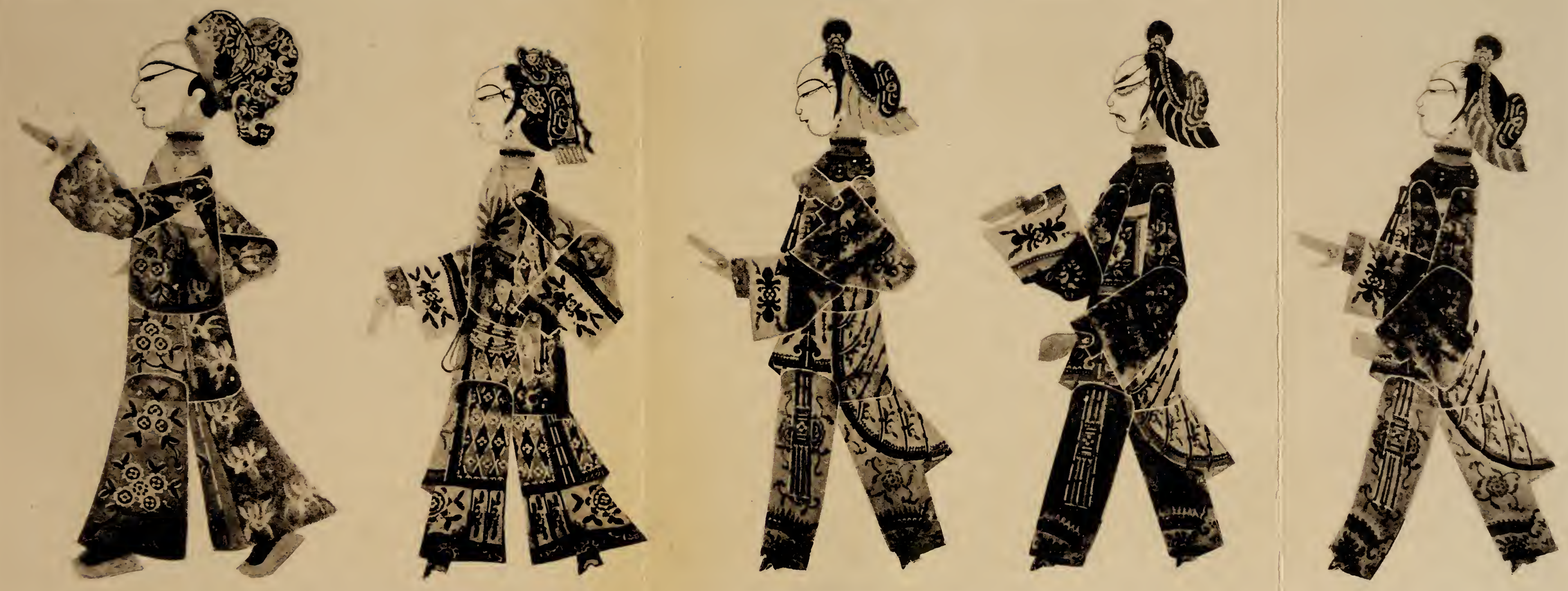

SHADOW-PLAY FIGURES, CHINA. STORY OF THE WHITE SNAKE (p. 41). Case 9, Bottom. 

the shadow-player excels, are the comic or satiric; he aims his wit at human weaknesses or, with merciless denunciation, condemns official corruption and other social and political evils. He thus pursues educational and moral purposes, especially when invited into the privacy of a family circle.

In Case 8 is shown a stage-scene with tree, flowerpots, table with embroidered cover, chair with a tigerskin spread over it, and the Buddhist patriarch Bodhidharma (Ta-mo). The paper figures on the bottom of the case are used as playthings by boys in Ch'eng-tu, capital of Se-ch'uan. On the other side of the screen are displayed a number of animals, such as horse, ox, swine, dog, elephant, lion, tiger, spotted deer, rooster, peacock, crane, pheasant, tortoise, fishes, oyster-shell, and dragon. In Case 9 are shown the complete casts of several famous plays, - a Buddhist drama in which figure the Eighteen Arhat crossing the sea, the story of the White Snake, a tragic love-play, and the Journey to India $(S i$ yu ki). This is a romance based on the journey to India of the celebrated pilgrim Hüan Tsang of the seventh century. $\mathrm{He}$ is shown in the act of carrying, suspended from a pole, the sacred manuscripts gathered by him during his peregrinations. He is followed by his white horse and his companions Sun Wu-k'ung, the king of the monkeys (the Indian hero Hanuman), Chu Pa-tsie with a pig's head, and the monk Sha Wu-tsing.

In Case 7 are displayed the masks of the same casts, as they appear on the stage. A word may be added about the character of the Pig-headed Companion, who in this allegoric story symbolizes the animal instincts of human nature. His surname Chu means "Swine," and a swine he is, not only in name and appearance, 
but also in disposition and conduct. His mouth and throat being very large, he is an omnivorous eater and swallows his food at one gulp, but does not perceive its taste. He carries under his arm a quire of coarse brown paper, as a vain pretense of being a literary man. He wears a long robe, to be considered a respectable character. He wears spectacles, in an unsuccessful attempt to hide his real face. He wears a helmet, on the vain assumption of being a great general: but when the roll is called, he beats his retreat. The only weapon he is able to handle is a rake with nine teeth. He sings ballads, but with so bad a rhythm and a tune that he frightens the life out of his hearers. In short, he behaved so exactly like a real hog, that one day when he was playing with a duck, each admired the other's exterior so much that even the innocent duck was deceived and mistook him for the genuine thing,-a swine. A widow proposed to blindfold him with a handkerchief, and promised to give him one of her three handsome daughters that he should catch. He found himself groping in darkness, embracing pillars and bumping against walls and doors, till at length, with bruised and swollen head, he fell on the floor, panting and exhausted.

\section{THE TIBETAN MYSTERY-PLAY}

Pantomimic dances with masquerades were cultivated in Tibet as far back as the seventh century A.D., when the country began to emerge from darkness into the light of history, and are described in the native chronicles dealing with the reigns of the early kings. At that time, these dances were part of the indigenous 


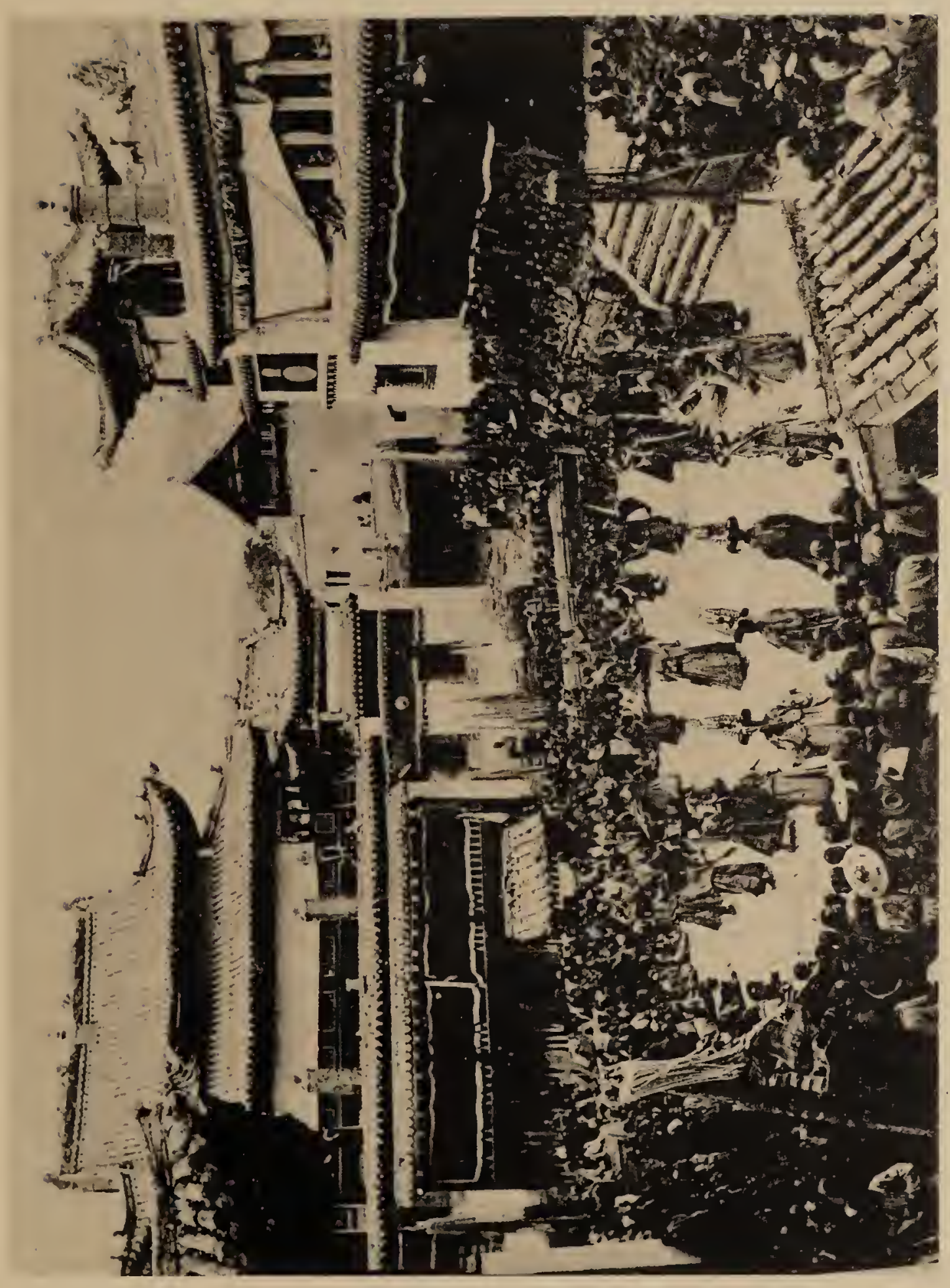

3
0
$z$
$x$
$z$
0
$w$
$w$
5
$w$
$w$
3

3
4
2
1
0
1
0

5

文 $\frac{u}{a}$

ㅁ.

ㄷ․

w

क

¿

z

5

뭉

F

山

I F

$F \geqq$

\&

$\sum$

I

4

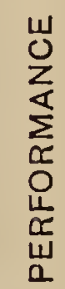


. 
shamanistic religion, and were chiefly designated to exorcise malignant demons and to ensure the favors of benign deities. With the introduction of Buddhism from India in about A.D. 630, these religious performances received a new impetus and drew fresh inspiration from the superior dramatic art of India. The fertile lore of the foreign religion supplied novel ideas, and although the ancient devil-dance was dressed up in a Buddhist garb, yet many of its former weird features were retained.

The Lamas, the ordained monks of the Tibetan monasteries, reserve to themselves the exclusive right to act in the mystery-plays and to represent, by means of awe-inspiring masks, the gods and demons in their numerous manifestations. This is consonant with the conviction that only the Lama, by virtue of his knowledge and sanctity, can wield authority over gods and demons; he only can, to modify a phrase of Hume, "perform ghostly offices." There is neither theatre nor stage in Tibet, the performances of the Lamas being enacted in the open air in the temple courtyards without any scenic equipment. No words, save wild outcries or interjections, are uttered; it is a pageant, entirely pantomimic in character, calculated to impress upon the onlooking multitude the omnipotence of the Church, the sway it holds over the demoniac and human enemies, and its ability to save the faithful from the clutches of the devils. This, in the main, is the object of most performances.

As to the deeper significance of the various acts, the laymen know hardly anything, and the Lamas, even though they may know, are reluctant to impart information to the inquisitive foreigner. But in most cases they do not know, and this is not strange, as they 
merely reproduce fixed and stereotyped forms inherited for centuries and contracted to such a degree of conventionality that their true significance was lost long ago. The Lama actors perform their roles in the same mechanical manner as they chant their litanies. With the flourish of trumpets, the sounding of gongs and shawms, and the clashing of cymbals, the mummery usually opens in the court-yard of a temple, which is crowded by men and women in festive attire. The galleries of the temple-buildings, hung with silken draperies, are reserved for the nobility and high dignitaries. As a rule, three or four Atsara (Case 17), with their tight-fitting one-piece garbs on which skeletons are painted, dash first into the arena to perform a terpsichorean extravaganza, pirouetting, leaping, hopping, bending their bodies backward and forward, waving their arms, and turning somersaults, or relapsing into a solemn movement, at a slow ballet-step accompanied by mystical and rhythmical motions of hands and fingers. There is no intermission, and one bewildering phantasmagoria follows closely upon the heels of the other, accompanied by the merciless strains of the orchestra. Different pantomimes are given in the numerous Lamaist monasteries of Tibet, Mongolia, and China. They vary also according to the season and holidays ; thus, there is, for instance, a special performance in honor of the Bodhisatva Maitreya, the Messiah of the Buddhists, and another in commemoration of the renowned hermit and poet Milaraspa. It is therefore impossible to give a typical description that would apply to all the performances.

The costumed figures with masks (Cases 13-17) are those employed on the festival of the New Year in the Great Lama Temple Yung-ho-kung at Peking. This 


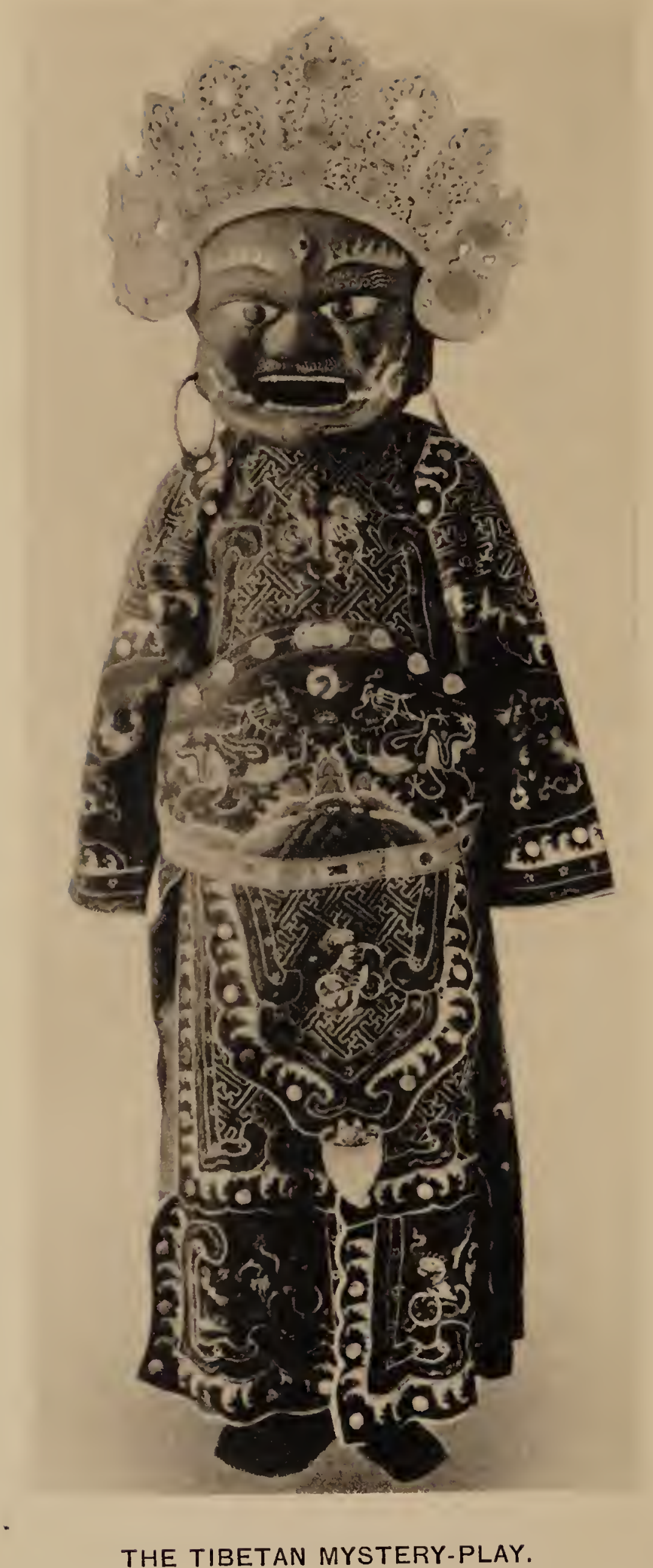

ONE OF THE HEAVENLY KINGS OR GUARDIANS OF THE WORLD (p. 45). 
pageant is designed to symbolize the departure of the old year, and to usher in good luck with the new year. It is opened by the big monk Ho-shang, who enters in the arena first, followed by the entire cast. The masqueraders line up in a row, the monk saluting each of them. As the representative of the clergy, he shows his reverence and makes obeisance to the gods. It is remarkable that he is not, as one might expect, a Tibetan monk or Lama. He is, in fact, a Chinese monk, and his smiling features indicate a genial and goodhumored soul. He is accompanied by six younger monks, who poke fun at him. He is said to be introduced into the play in remembrance of an historical Chinese monk, called Ho-shang, who came to Tibet from China in the eighth century to enjoy a religious disputation with his Tibetan confrères; these, by their superior wit, scored heavily against him,-at least, so the Tibetans claim. The Tibetan and Mongol Lamas were strongly established and upheld in the capital by the Manchu dynasty for political reasons, as a means of maintaining control of Tibet and Mongolia. It may be that the choice of the defeated Chinese monk was a piece of political propaganda on the part of the Lamas to emphasize their own superiority over the Chinese monks, whom they despise with all their heart. The principal casts are derived from the mythic lore of India. First come the Red, Black, and Blue Kings (Case 13), terrifying embodiments of the so-called Heavenly Kings or Guardians of the World, who are stationed at the foot of the world-mountain Sumeru, guarding the four quarters and combating demons. Their statues are found at the entrance of every temple. They are provided with the eye of wisdom on their foreheads, which enables them to penetrate the past, 
present, and future. Flames surround their lips, and their mouths are wide agape to indicate that their roaring voice terrifies the demons. Their costumes, embroidered in gold with dragons and lions, are suggestive of armor which alludes to their war-like profession. Two other Kings (Case 15), being yellow and red, wear a wreath of five skulls and on the top of their heads a thunderbolt (vajra) surmounted by three flaming jewels. These are emblematic of Buddha, his law, and the clergy. Their costumes are embroidered with dragons rising from the ocean.

The Green-blue, Brown, and Light-blue Officials (Cases 14-15) belong to the retinue of the Guardians of the World who precede them. The masks of this group are of the same style, and are adorned with the same attributes as those of the Great Kings, save that in the place of the gilded crown they wear a wreath of skulls surmounted by the thunderbolt. As warriors they are clad in a costume, after the style of armor, embroidered in gold thread with combating dragons. Each of these is credited with having ninety-one sons, and is attended by eight generals and twenty-eight classes of demons. In their world (the devaloka) life lasts five hundred years, but twenty-four hours there equal fifty years on earth. The two female fairies (Case 14) with head-dresses and costumes of Chinese style belong to the retinue of the goddess Lha-mo.*

The mask with the head of a bluish bull (Case 16) represents Yama, the ruler of the dead, in this form known as the King of the Law (Dharmarāja). He is the most powerful of the guardian-deities of Lamaism, and is able to protect his adherents from all adversaries. His appearance in the pageant is calculated to impress upon the spectators thoughts of the here- 
after and the dreadful spirits from whom the Lamas alone are able to deliver them. The deer-spirit is Yama's messenger. White spots are brought out on the mask, and plum-blossoms are embroidered on the costume, because this species of deer (Cervus mandarinus) is known as "plum-blossom deer."

The Yellow Mule (Case 16) is the animal sacred to Lha-mo. When the goddess made her escape from Yama's kingdom on the back of this divine mule, Yama discharged an arrow at him, but Lha-mo transformed the wound into an eye. More information on this goddess is given below (p. 49).

The Dakini (the Tibetan term means "roaming through the air") are a class of aerial fairies, mainly female sprites, akin to our witches, but not necessarily ugly or deformed. They are possessed of supernatural powers, bestowing blessings on saints and women and battling evil demons. There are numerous groups of them, one being called the Fairies of Wisdom. To these belong the Lion-headed Dakini, who appears in the Lamaist pageant (Case 17), and the Dolphin-headed Dakini (Case 16), who has the head of a fantastic sea monster (makara) with elephant-like trunk and tusks and a pair of horns on the head. The masks of the lion and tiger are in Case 17; the latter is explained below (p. 51). At Peking, the procession is closed by the Atsara, the ghoul with skeleton painted on his white cotton garb.

The Tibetan masks are very instructive in that they make us acquainted with the mythology and many religious concepts of the people. Among female deities, Târā is the greatest favorite. She is adored as the savior from the cycle of transmigration. She appears in twenty-one manifestations (Case 10), each 
of these being invoked by different prayers and charms, and each having the power of rescuing people from a certain danger of affliction. The most popular two of these are the so-called White and Green Tārā The two wives of the first Tibetan king, who ruled in the first part of the seventh century A.D., are believed to have been incarnations of these goddesses. One of these was a Chinese princess, daughter of the emperor 'T'ai-tsung of the T'ang dynasty who introduced into Tibet silkworms and silk-weaving as well as refined manners. The other was the daughter of Amçuvarman, king of Nepal. Both princesses were devout followers of Buddha, and assisted their husband in propagating Buddhist teachings and the higher culture of China and India. Because of their merits they were subsequently canonized as saints and worshipped under the images of the two Tārā. It is a curious fact that the empress Catherine II of Russia was looked upon as an incarnation of the White Tārā by the Buryat, a Mongol tribe inhabiting the region of Lake Baikal.

In the complex pantheon of the Lamas there is a special class of deities who are pledged to guard Buddha's religion and defend it by means of arms against demons and human enemies, and each god has a distinct sphere of power assigned to him. They are called defenders of the faith (Sanskrit dharmapāla). In the mystery-plays a group of sixteen Dharmapāla (Case 12) make their appearance to impress upon the world the preparedness of the clergy and their readiness to strike terror into the hearts of their opponents. They, are represented in so-called mild and wrathful or terrifying forms, more commonly in the latter. In the mild form they defeat the enemies of 
the faith and triumph victoriously. They spy their adversaries at a great distance, appall them with a blaze of flames which constantly surround them, and smite and annihilate their foes with potent weapons. The Sixteen are headed by Yama, the grim god of death with protruding tusks, flaming head-dress, and five skulls hung over his forehead, and by the bloodthirsty Durga, the consort of Chiva; they end with Telopa, a famed Indian magician, who actively opposed the advance of Islam. Islam, on the one hand, and Christianity, on the other hand, still cause uneasiness and anxiety to the Lamas, who practically are the landowners and rulers in Tibet.

Another bulwark in the defence of the faith is formed by Lha-mo, which means "the Goddess," who is simply so called because she is a great favorite with both clergy and laity, and her real name is held too much in awe to be pronounced. She is an incarnation of the Hindu goddess Kāli, who still presides over the nationalistic movement of the Bengali, and is the subject of a lengthy cycle of legends. She is the patroness of Lhasa, capital of Tibet, where a great mass is celebrated in her honor on the first day of the first month. In the mystery-plays are shown twenty-four emanations of the goddess intended to illustrate the sequence of her legendary story (Case 10). Thus, in the first mask, she is represented in the act of devouring her son. The story runs that formerly she was the spouse of Yama, god of death, before he was converted to Buddhism, and had from him a son who, it was prophesied, would turn an enemy to Buddha's doctrine. She therefore slew her son, flayed him, and saddled a mule with his skin. She escaped from Yama's realm astride this mule, although Yama shot an arrow at the 
animal. Finally she enlisted among the defenders of the Buddhist religion. In the following masks she is shown with the face of a sea-monster, devouring a snake, and with the face of a lion. Again, she appears as bestowing blessings and longevity, as the protector of the land, exulting over her victories, and finally as the queen of the four seasons.

-An interesting group of masks is that representing various animals (Case 11), many of which personify ancient pre-Buddhistic deities of Tibet which take us back to the threshold of a prehistoric age when the gods were embodied in the form of animals, and when the worshipper, in assuming the name and semblance of the gods, believed that he identified himself with them. Prominent in ancient Tibetan mythology is the Raven. It was a sacred bird of solar character, a bird of augury who functioned as the messenger of the supreme deity. From his voice the will of the god was interpreted, and his predictions appeared as the expression of divine providence. It is curious that the mask designated by the Tibetans as that of the Raven is very unlike this bird. It is dark green in color, with curved and hooked red bill, while the raven's beak is straight. A blue eye of wisdom on the forehead, flaming eyebrows, and gold-painted flames protruding from his jaws complete its characteristics. This coincides with the make-up of the mythical eagle Garuda of India, which serves as vehicle to Indra, and is the sworn enemy of the serpents. In the pantomimic dances of the Lamas the Raven attempts to pilfer the strewing oblation, and is driven away with long sticks by two Atsara, ghouls represented by a skeleton which is outlined on their cotton garbs, and equipped with masks having the appearance of skulls (Cases 10 and 


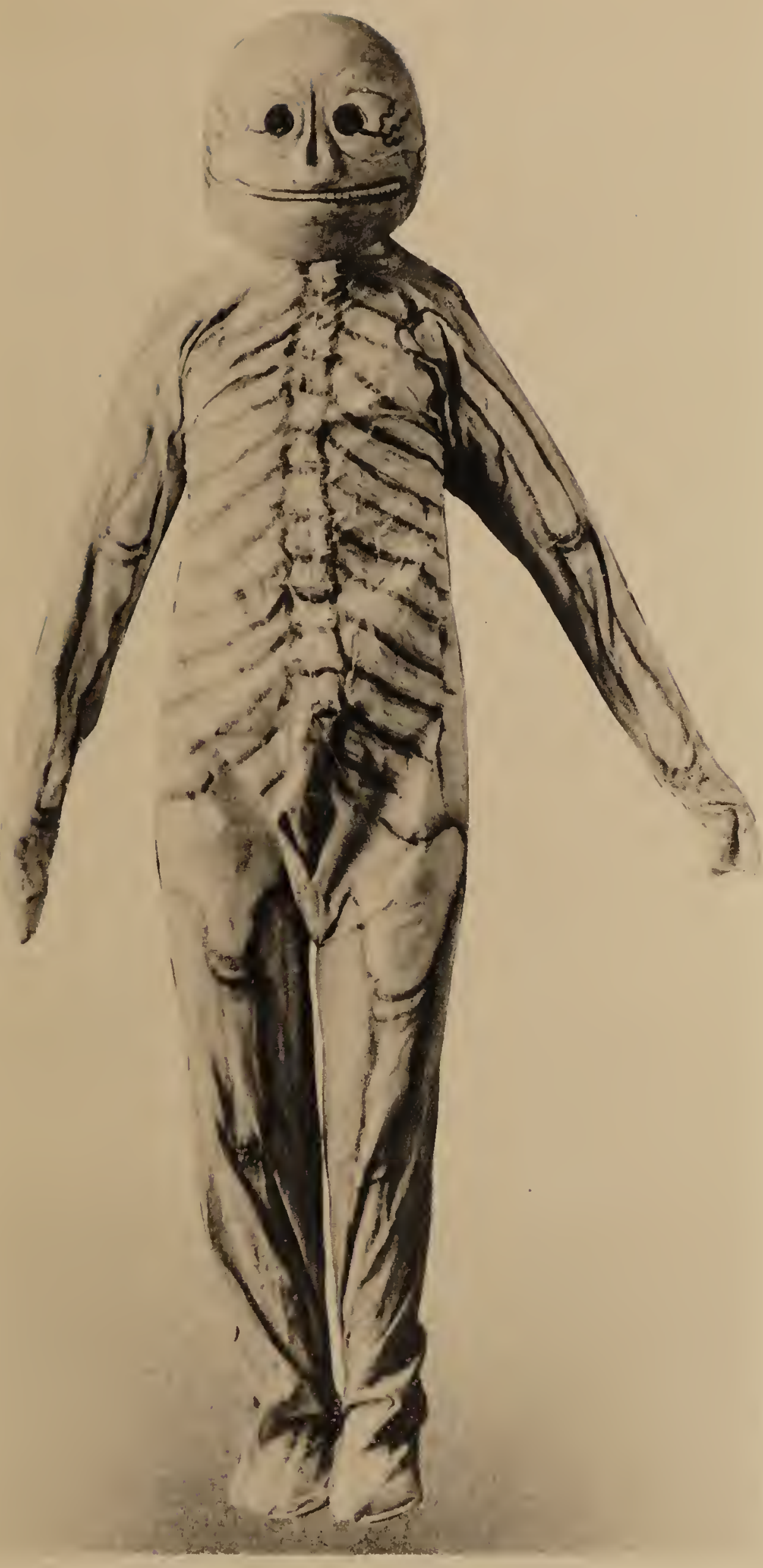

TIBETAN MYSTERY-PLAY.

MASK AND COSTUME OF ATSARA (pp. 44, 47, 50). 

16). They play the parts of buffoons. The corresponding Indian tradition is that Garuda captures the soma (an intoxicating beverage) or the nectar (amrita) destined for Indra. He once even defeated the host of the gods, killed the guardians, extinguished the fire surrounding the nectar, and made away with the latter. Apart from Indian notions, the Tibetan Raven is also imbued with Persian-Mithraic elements, being equipped with six wings and six pinions in ancient texts. In the belief of the Persians, the raven was sacred to the god of light and to the sun; on the Mithraic monuments he perches behind Mithras, who sacrifices a bull. In addition to this, the first of the seven degrees of initiation, which the mystic successively assumed in the Mithraic worship, was styled "Raven."

A very important deity is the tiger, dreaded and worshipped all over eastern Asia. In Tibet he is conceived of as a powerful god living under ground, where he guards great treasures. Many local deities assume, or are represented in, the shape of a tiger. The tiger dance originated in times ante-dating Buddhism, and is connected with the native shamanistic form of religion. It was intended to expel the old year with its demons of ill luck and to propitiate the war-god and the guardian spirits, in order to secure triumph over enemies during the incoming year. The masks of the monkeys likewise are significant. The monkey belonged to the sacred animals of the ancient Tibetans, and was sacrificed together with sheep and dogs once a year, when the high officers assembled for the ceremony of the minor oath of fealty. In their recorded traditions the Tibetans have preserved at great length the story of how they descended from the alliance of a monkey with 
a female giant (Rākshasi). The Rākshasa are mandevouring demons of Indian mythology, adopted by the Tibetans; their masks are shown on the same screen (Case 11).

In Case 11 is shown a series of ancient masks obtained directly from monasteries in the native Tibetan kingdoms of western Se-ch'uan. These masks are made by means of layers of cloth and paper, and have suffered much from wear and tear. One represents a Brahman of India. Others represent a Hindu layman; Māra, the personification of the evil principle, who tempted Buddha; the famed Indian hermit called Unicorn (cf. Chinese Clay Figures, p. 112 and Plate X) ; and the dolphin-like marine monster makara.

The Tibetans have also a literary drama, the plots of which are all Buddhistic, the style and technique being in imitation of Sanskrit models. There is, further, a popular drama with plots derived from the same source and enacted by professional laymen (not Lamas). Such plays are usually performed in the open air on the occasion of a festival and at the expense of some well-to-do person, the public being admitted free. Few of the actors know their roles by heart, and most of them read the text from a book. It is not a drama in the proper sense of the word, but a story in dramatized form recited, not acted. These itinerant comedians avail themselves of flat cloth masks stuck over with cowries or of painted woodcarved masks (Case 11). The clown, whose buffoonery is constantly in evidence, wields a large stick in his hand. The dancers wear a cap and a plaited girdle of yak-hair and hemp, brass bells being attached to it. This outfit was secured from a party of comedians at Chamdo in eastern Tibet. 


\section{THE THEATRE IN JAVA}

In Java there are various forms of theatrical representations. The oldest and most important of these is the shadow-play, which is referred to in Javanese poems of the eleventh and twelfth centuries. The figures for the shadow-play are cut out of dried buffaloskin, and are usually elaborately painted and gilded. There are two varieties with separate names, differing chiefly in the character of the plays presented. In the older one (wayang purwa), these are for the most part derived from the old Indian epics, Mahābhārata and Ramanyana. While the characters and incidents of the stories can usually be easily identified as of Indian origin, the scenes have been transferred to Java, and the people universally regard these stories as relating the adventures and activities of their own ancestral heroes and deities. Among these stories are some, however, that are derived from old Javanese legends and myths, and hence of local origin. As the plays represent the activities of superhuman heroes and deities, they have a religious character, and even to the present day an offering of food is made, and incense burned, before each performance. In the second form (wayang gedog) of the shadow-play, the characters and plots are based on Javanese history and legends, and have to do largely with the various adventures of the famous hero Panji. The figures used differ somewhat from those in the wayang purwa, the music is in a different scale, and the religious associations are lacking.

A more recent development of the Japanese theatre is the puppet-play (wayang golek), in which the characters are represented by wooden puppets with mov- 
able arms (Cases 18-19). This is most common in western Java, where it probably originated under Chinese influence, and where it has displaced the older shadow-play to a large extent. In central Java it is less common. The repertoire includes not only all the stories used in the shadow-play, but also many of more recent origin relating to Mohammedan and Malay heroes. The general character of all these stories is much the same, having to do largely with the love adventures and war-like exploits of the principal hero and his attendants. To set off the hero, there is always the opposing group with its leader,-the enemy chieftain or the rival in love. While the hero has every noble quality, his opponents are frequently quite the reverse, and are often represented as in league with demons and evil spirits. These also appear in the plays, and are represented by certain of the puppets.

The puppets representing the two opposing groups are distinguished by certain characteristics, the hero and his associates being lighter in color and more noble in appearance. The prince and princesses on both sides are represented with crowns and special ornaments. Clowns and buffoons are frequently present, and serve to break the monotony of the performances, which are often very long, continuing sometimes for several days. A skilled operator (dalang) will also introduce local touches, much to the delight of his audience. If Europeans are present, a sly hit may be made at some of their foibles. These humorous and local touches add greatly to the popularity of the performance.

The puppets are usually shown through an opening in a curtain or screen. The head and body are of separate pieces, the head being fastened to a long stick; 


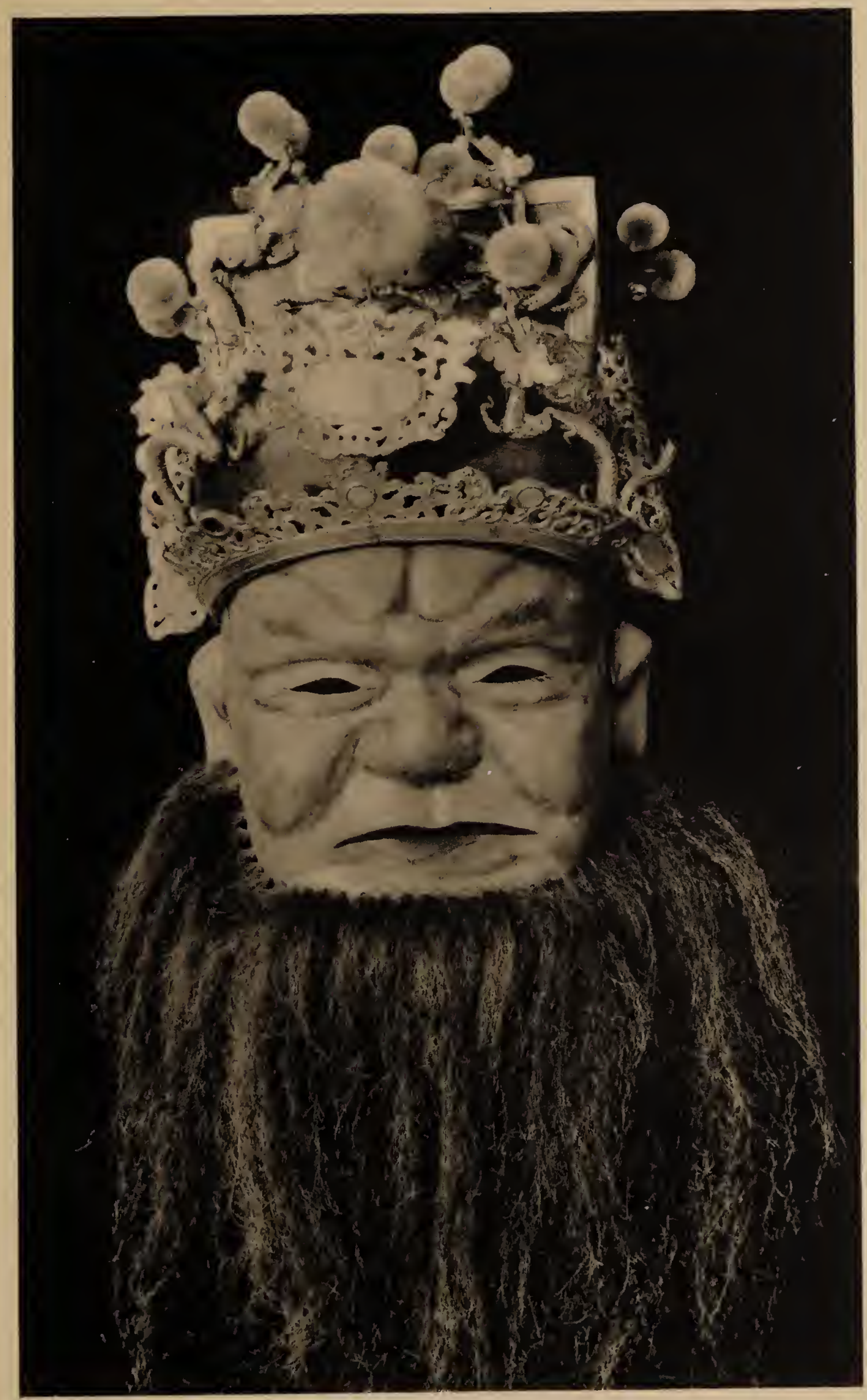

MASK OF CHAO KUNG-MING, CHINA (p. 34). 

which passes through the body, having an enlargement or crosspiece on which the body rests. As the sarong or clothing covers the lower part of the puppet, the legs are lacking, and the lower end of the stick is held by the operator (dalang), who at the same time moves the sticks attached to the arms with his thumb and forefinger. The puppets not in use are stuck in a banana stem on each side. The dalang, of course, recites the story, as well as operates the puppets. He also directs the orchestra, which is placed behind him.

Music is a very important feature in every theatrical performance. The orchestra not only plays before and between acts, but certain instruments often play during parts of the performance, and indicate the nature of the action taking place. All this is controlled by the operator (dalang). The orchestra consists of a variable number of musical instruments (Cases 20-21), according to the character of the performance. There are two different musical scales, one having seven notes to the octave, the other only five. All the instruments of any one orchestra would be arranged on the same scale. The one with five notes seems to be the older, and the orchestra having this scale (gamelon selendro) is regarded as the best. It is the one used with the old shadow-plays. In both cases, the instruments are the same, except for the number of keys. Most of the instruments are instruments of percussion-xylophones, drums, gongs, and similar instruments;-but there are also two stringed instruments and sometimes a flute. One of the stringed instruments (rebab), with two copper strings, is always present, and is played by the leader of the orchestra. The instruments, of course, vary greatly in the care and expense bestowed upon their manufacture. The finest orchestras 
belong to the princes and nobles of central Java, and their value often runs into thousands of dollars.

The true theatre, in which living actors represent the characters of the story, is probably of independent development. There are two forms, - the topeng, in which the actors wear masks (Case 22), and the wong, in which they are without masks, and speak their own parts. In both forms rather elaborate head-dresses (Case 23) and costumes (Case 24) are worn. Masked plays (topeng) are referred to in old Javanese literature, and in Java are at least as old as the shadow-play, but do not seem to have been so popular, probably owing to the expense. The wong, which is much the same as the topeng, with the masks and operator (dalang) omitted, was first introduced about the middle of the eighteenth century by one of the princes or sultans of central Java, and soon came into common use. Dancing and posturing form a very important part of the performance in either case, and long courses of training are necessary to fit the actors for their parts.

The best performances are to be seen at the courts of the ruling princes of central Java, where the actors and dancers belong to the prince's retinue. Smaller and less elaborate performances are fairly common, however, and there are small traveling troops of players and dancers who give simple performances in the villages. The stories are the same as those in use in the shadow and puppet plays. Masks may, or may not be used.

The masks (Case 22) are made of light wood, painted and decorated to represent the different characters; the differences corresponding to those shown in the wooden puppets. They are kept in place by 
means of a loop of rattan or a strip of leather held between the teeth. As in the puppet-play, the operator (dalang) recites the story, though the actors may occasionally speak their own parts, in which case the mask is held before the face with one hand.

The head-dresses (Case 23) are worn more especially by the actors impersonating kings and princes. The best head-dresses are made of leather or rawhide, but thin beaten brass or copper is also often used. Similar head-dresses may be seen represented on the old stone figures and sculptures of central Java.

The information contained in this chapter has been supplied by Assistant Curator A. B. Lewis.

\section{SINGHALESE MASKS}

There are two distinct groups of these masks, - one used in dramatic performances; the other, by sorcerers in the healing of disease.

The masks displayed in Case 25, elaborately carved from wood and painted in bright colors, are employed by itinerant actors in pantomimes and comedies performed in the villages of Ceylon. A slit made under the eye enables the actor to see. The patterns are very ancient, and are always strictly reproduced. Some, like the uncolored carving in the left lower corner of the screen, have artistic merits. Little is known about these Singhalese performances and the significance of the individual masks.

The wood-carved and painted masks displayed in Caseś 26-28 represent demons, and are used in devildances purported to heal various diseases. Whenever an individual is ill, he summons the sorcerers supposed 
to have power over the devil causing the complaint. The ceremony and the dance connected therewith are very elaborate. A throne room is built and decorated with fresh leaves, flowers, and plantain-stalks, and is illuminated with hundreds of torches dipped in oil. In front are placed seven floral steps. The patient is made to wear a crown, anklets, armlets, bracelets, belts, etc., made of stems of tender creepers. The performers are dressed in ornamental hats, bodices, and skirts. The chief sorcerer wears the mask and costume of the devil by whom the patient is possessed. After the recital of many invocations, charms, and songs, all decorations are cut down, and the demon of disease is supposed to be exorcised. The underlying idea is that he has taken his abode in the devil-dancer, who is placed on a bier and carried as dead out of the village. The devil, believing that the sorcerer is dead, will voluntarily forsake his body to seek another victim.

In the uppermost row are shown masks representing animals, in the second row turbaned Mohammedans, in the two lower rows masks with high or elaborate head-dresses and some without head-gear.

Special attention is called to the mask of Nägeçvara (Case 27), a serpent-demon or Nāga surmounted by the image of a seated Buddha overshadowed by a cobra, -a favorite theme of Buddhist lore, and to the serpent-demons, male and female, representing Nāgas. These are evil demons believed to be personifications of venomous serpents and to cause diseases, especially leprosy. They have demoniacal faces with bulging eyes and large protruding tusks. Their heads are surmounted by cobras standing erect. In some examples serpents are to be seen stretching along their upper lips, in others they are crawling into their nostrils. 
In Case 28, the Rākshasa and Yaksha are grouped together. These demons are man-eaters, feeding on the flesh of corpses and drinking human blood. They are believed to have been the earliest inhabitants of Ceylon. There are many classes of them, and for each there is a different ceremony for its propitiation, which includes offerings and dances accompanied by music. 


